\title{
COVID 19 koşullarında sağlık çevirmenliği hizmetleri ve toplum çevirmenliğinde "Yeni Normal"'i düşünmek
}

Filiz ŞAN 1

\section{Rana KAHRAMAN DURU²}

\begin{abstract}
APA: Şan, F.; Kahraman Duru, R. (2020). COVID 19 koşullarında sağlık çevirmenliği hizmetleri ve toplum çevirmenliğinde "Yeni Normal”'i düşünmek. RumeliDE Dil ve Edebiyat Araştırmaları Dergisi, (20), 816-843. DOI: 10.29000/rumelide.792521.
\end{abstract}

\section{$\ddot{O} \mathbf{z}$}

Dünyayı etkisi altına alan COVID-19'un ülkemizdeki ilk vakaları 2020 Mart ayı başında görülmüştür. Hastalığın yayılması hem dünyada hem de Türkiye'de diğer alanlarla birlikte iş dünyasını da büyük ölçüde etkilemiş ve bu durumun çeviri sektörü ve çevirmenlik hizmetlerine çeşitli yansımaları olmuştur. Bu bağlamda, içinde bulunulan sürecin sosyal, ekonomik, ticari vb. tüm alanlarda yeniden düşünme, gözden geçirme ve hatta köklü değişiklikler yapma gerekliliğini ortaya çıkaracak nitelikte olduğu düşünülebilir. Hiç kuşkusuz, sağlık sektörü bu dönemde en çok etkilenen alanların başında gelirken, sağlık çevirmenliği hizmetlerinin COVID-19 koşullarında nasıl verildiği sorusu da araştırılmaya muhtaç bir konu olarak belirginleşmiştir. Bu ihtiyaçtan hareketle pandemi süreci özelinde sağlık kuruluşlarına başvuran hastalara ve sağlık personeline çevirmenlik yapan kişilerin durumunu ve çalışma koşullarını ortaya koymayı amaçlayan bir anket uygulanmıştır. Anketten elde edilen veriler, Toplum Çevirmenliğinin "yeni normal"i açısından irdelenmiş ve meslekleşme/profesyonellik sürecine etkileri bakımından değerlendirilmiştir.

Anahtar kelimeler: Sağllk çevirmenliği, yeni normal, toplum çevirmenliği, covid-19, çevirmenlik mesleği

\section{Thinking about "New Normal" in healthcare interpreting and community interpreting in terms of COVID-19 conditions}

\begin{abstract}
Having influenced the world from the end of 2019, COVID-19 manifested itself with its first cases at the beginning of this year in our country as well. Industries both across the world and in Turkey have been greatly affected by the spread of the disease. This, in turn, has had several effects, both positive and negative, on translation/interpreting sector and services, as well as many other sectors. In the meantime, the concept "new normal" has emerged as a paradigm forcing us to rethink fundamentally in all areas within the social, economic, and commercial framework. Undoubtedly, since the healthcare sector is one of the most affected areas during this pandemic, the question of how healthcare interpreting and translation services are provided under COVID-19 conditions arises as a topic requiring research. Based on this need, a survey was applied to reveal the situation and working conditions of the healthcare interpreters and translators who translate for the health professionals and patients in healthcare institutions, with a focus on the pandemic process. The present study Dr. Öğr. Üyesi, Sakarya Üniversitesi, Fen Edebiyat Fakültesi, Mütercim ve Tercümanlık Bölümü (Sakarya, Türkiye), fsan@sakarya.edu.tr, ORCID ID: 00oo-00o3-2158-3818 [Makale kayıt tarihi: 24.06.2020-kabul tarihi: 20.09.2020; DOI: 10.29000/rumelide.792521]

$2 \quad$ Öğr. Gör. Dr., Marmara Üniversitesi, Fen Edebiyat Fakültesi, Mütercim-Tercümanlık Bölümü (İngilizce), Yarı zamanl, (İstanbul, Türkiye), ranakahraman@gmail.com, ORCID ID: 0000-0001-5908-4040
\end{abstract}


examines the findings of this survey, which was carried out specifically for healthcare interpreters and translators, in terms of the "new normal" concept for the Community Interpreting, and evaluates them in terms of this new normal's effects on the professionalization/professionalism process.

Keywords: Healthcare interpreters and translators, new normal, community interpreting, covid-19, translation and interpreting profession

\section{o. Giriş}

20. yüzyllın sonlarında, bilim ve teknolojide gelişim, yapay zekâ, dijitalleşme ve her geçen gün artan internet kullanımı, özellikle 1990'lı yllarda, hizmet sektörünü tetiklemiş, küresel şirketleri uyum sağlayamadıkları takdirde kendilerine karşı birer tehdit unsuruna dönüşecek risklerle karşı karşıya bırakmıştır. Terör, kurumsal skandallar, iflaslar, küçülen ekonomiler, pek çok standartlaşmış dev yapılanmayı yenilikçi, akılcı, ilkelerden taviz vermeyen, etik bir halde kalmaya ve sürekli uygulama yönünde ilerlemeye mecbur kılmıştır.

McNamee tarafından ilk olarak 2004 yılında ortaya atılmış olan, "Yeni Normal" olarak adlandırılan yaklaşım, küresel anlamda zaman algısının, yatırım kararlarının ve rekabet yeteneklerinin değişmesi açısından yeni, ancak bu değişikliklerin en az on yıllık sürede yerleşecek olmasından ötürü normaldir. Yeni normal, adapte olamayanı yok edeceği gibi, birçok fırsatı da beraberinde getirecektir. Kriz sonrası geleneksel ekonomik göstergeler farklılaşırken, çeşitli açıdan yeni alışkanlıklar kazanılacaktır (McNamee, 2004). Covid-19 sürecinin ekonomik göstergelerinden yola çıkarak bakıldığında ise, 2004 yllında ilk defa karşllaşllan bu kavram, toplumların değişip dönüştüğü bütün dönemlerle ilişkilendirilerek ele alınıp kullanılabilme özelliğinde dinamik bir tanıma sahiptir.

Öte yandan içinde bulunulan durumu son yirmi yılda ülkemizde daha yakından aşina olduğumuz afet yönetimi kavramları ile açıklamak gerekirse, "afet", toplumun tamamı ve belli kesimleri için fiziksel, ekonomik ve sosyal kayıplar doğuran, normal hayatı ve insan faaliyetlerini durduran, kesintiye uğratan, etkilenen toplumun baş etme kapasitesinin yetersiz kaldığı, doğa, teknoloji veya insan kaynaklı olaylar ve bu olayların oluşturduğu kriz hali olarak tanımlanmaktadır. 3

Bu tanımdan yola çıkıldığında Covid-19 "küresel bir afet" olarak nitelendirilmektedir. Ancak müdahale aşamalarının bir acil durum ve afet müdahalesi kapsamında yapılandırılmasını gerekli gören bir yaklaşım karşısında, bu durumun iklim değişikliğine bağlı olduğu öne sürülen, bu nedenle salgınların iklim değişikliği sorunları ile bir arada ele alınması gerektiği savunulan tartışmalar da bulunmaktadır. Aynı tartışmalar bağlamında, "normal”e dönme diye bir durumun söz konusu olmadı̆̆ı iddiasından hareketle, bundan böyle gerek toplumsal yapılanmalarda gerekse kullanılan kavramlar anlamında "yeni” normale ihtiyaç duyulduğu ifade edilmektedir.

Afet olgusu standart tanımlamalar dahilinde afet öncesi hazırlık, afet ve afet sonrası iyileşme süreçleri olarak sinıflandırılabilir. Ancak bu pandemi/afet/kriz, bugüne kadar (özellikle Türkiye'de) yapılan bütün tanımlamalardan farklı, bir anda olup bitmeyen, hemen iyileşme sürecine geçilemeyen, henüz netlik kazanmamış ve ancak farklı alanlarda uzun vadede tamamlanacak bilimsel ve ampirik araştırmalarla yeni normal yapısı içinde görünürlük kazanacak bir durumdur.

35902 sayılı Afet ve Acil Durum Yönetimi Başkanlığının Teşkilat ve Görevleri Hakkında Kanun https://www.afad.gov.tr/kanunlar

4 https://www.sivilsayfalar.org/2020/04/23/salginla-mucadelede-en-onemli-koz-afet-yonetimi/ 
Thinking about "New Normal" in healthcare interpreting and community interpreting in terms of COVID-19 conditions / F. Şan; R. Kahraman Duru (pp. 816-843)

Buna göre araştırma kapsamında, COVID-19'a müdahale sürecinin standart "normal" tanımlamalarından farklı bir durumsallık içerdiği savından yola çıkılarak, sağlık çevirmenlerinin ortamın eyleyicileri olarak içinde bulundukları söz konusu "yeni normal" yapılanmasında, genelde Toplum çevirmenliği, özelde de Sağlık çevirmenliği açısından yeniden düşünülmesi gereken alanların görünür hale getirilmesi amaçlanmaktadır.

\section{Sağlık hizmetlerinde toplum çevirmenliği}

Toplum çevirmenliği, özellikle kültürlerarası hareketliliğin hem doğal nedenlerle hem de insan ya da doğa kaynaklı afetler sonucu artmasıyla, iletişimin gerekli olduğu her koşulda daha da belirgin bir ihtiyaç olarak ortaya çıkmıştır.

Toplum çevirmenliğinin öteki sözlü çeviri türlerinden farkı durumsallğın daha da yoğunluk kazanmış olmasındandır. Buna göre koşulların getirdiği tüm olumsuzlukları aşabilme yetkinliği ile nesnelliğin korunarak iletişimin olabildiğince işlevsel bir biçimde sağlanması esastır. Durumsallı̆̆ın getirdiği rollerin ve koşulların ayrımına varmak, sürecin gerekliliklerini yerine getirmek gibi değişken ve geçişli rol tanımları içinde, standartlaştırılması için çalışılan bir alan, Yeni tip korona salgını ile gündemimize giren "yeni normal" bağlamında bugüne kadar yapılmış tanımların ötesinde yeni tanımlamaları da gerekli kılmaktadır.

Normal koşullarda, bir hasta-doktor görüşmesi sürecinde çevirmenin hizmet vereceği fiziksel koşullar nispeten daha uygun, temiz ve rahatlatıcı olmalıdır. Ancak deprem gibi afet koşullarında, arama kurtarmacı ile bir enkazın altına uzanarak içerideki afetzede ile iletişimi sağlamak çevirmenin kararlarını etkileyen zorlu fiziksel durumlara verilebilecek bir örnektir (Kahraman 2003: 38-46).

Bir mülteci kampında sığınma başvurusunda bulunanlara, kampın tüm olumsuz koşullarına karşın çeviri yapmak da çevirmeni insani boyutta zorlayabilir. Örneğin tecavüze uğramış, töre cinayetinden kaçan bir kadının ya da işkence görmüş bir insanın görüşmesi sırasında yapılan çeviriler toplum çevirmenliğinde karşılaşılan vakalardan yalnızca birkaçıdır. Tüm bu çeviri ortamlarında karşılaşılan koşullar çevirmeni ister istemez fiziksel ve psikolojik olarak zorlayacaktır. Bu durum çevirinin niteliğini ve çevirmenin karar alma süreçlerini etkileyebilir. (Kahraman 2010: 42).

Toplum çevirmenliği, bu hususların da işaret ettiği gibi, standartları pek çok ülkede son yirmi yılda kendini göstermeye başlayan bir alandır. Bir faaliyet olarak geçmişinin çok daha eskilere dayanmasına karşın toplum çevirmenliğinin bir terim olarak kullanılması ancak 20. yüzyılda gerçekleşmiş, Franz Pöchhacker tarafından da bu faaliyete kamu hizmeti çevirmenliği ${ }^{5}$ adı altında yer verildiğine dikkat çekilerek, süreçte yer alan çevirmenlerin çoğunlukla profesyonel olmayan kişilerden oluştuğuna ve bu alanda profesyonelleşmeye ihtiyaç duyulduğuna işaret eden tanım getirilmiştir (Öztürk 2015: 39). ${ }^{6}$

Toplum çevirmenliğini gerçekleştiği ortama göre farklı kategoriler altında incelemek mümkündür. Sağllk sektörü, mahkemeler, mültecilik süreçleri, polis sorgulamaları gibi pek çok ortamda ihtiyaç duyulan toplum çevirmenliği hizmetleri arasında, sağllk sektöründeki toplum çevirmenliği türü, uygulamanın yoğun olduğu sahalardandır.7

İngilizce: public service interpreting. (Bkz. Pöchhacker, 2004)

Bu alanda çalışan bir çok araştırmacı da profesyonelleşme, standartlar ve uygulamaları karşılaştırmalı olarak ele almıştır. Konuyla ilgili ayrica bkz. Aguilar-Solano (2015), Bolden (2000), Mikkelson (2012).

Bkz. Diriker \& Tahir-Gürçağlar (2004), Hale (2007). 
Toplum çevirmenliğinin Türkiye'de görünürlük ve standart bir çerçeve kazanması, 15.12.2018 tarihli Mesleki Yeterlilik Kurumu Ulusal Yeterlilik Taslak Belgesi'ndeki Toplum Çevirmenliği başlı̆̆ altında, Madde 8'deki AMAÇ bölümünde yer alan tanım ile olmuştur8,

- Bu yeterliliğin amacı, kamu veya sivil toplum kuruluşlarının sunduğu hizmetlerden dil farklılığı nedeniyle yararlanmakta güçlük çeken bireylere ve hizmet sağlayıcılara, kolluk kuvvetleri birimlerinde, adli süreçlerde, sağllk ve eğitim ortamlarında, devlet kurumlarında, yerel yönetim, acil durum ve afet, çatışma, göç, sığınma sahaları ve spor ortamlarında sözlü çeviri hizmeti veren toplum çevirmenlerinin yeterliliklerini ve değerlendirme ölçütlerini belirlemek,

- Adayların, geçerli ve güvenilir bir belge ile mesleki yeterliliğini kanıtlamasına olanak vermek,

- Yükseköğretim sistemine, sınav ve belgelendirme kuruluşlarına referans ve kaynak oluş̧urmaktır.

Bunlara ek olarak son yıllarda gelişen sağlık turizmi ile birlikte kurumlarda artan dil ihtiyacı, çevirmen kadrolarının istihdamı ile daha görünür hale gelmiştir.

Bu bağlamda sağlık çevirmenliğinin yasal çerçevedeki görünürlüğü incelendiğinde, 13.07.2017 tarihli ve 30123 sayılı Resmî Gazete'de yayımlanarak yürürlüğe giren "Uluslararası Sağlık Turizmi ve Turistin Sağlığı Hakkında Yönetmelik" (2017), öncelikle Uluslararası Sağlık Turizmi Birimi bünyesinde çalışan kişilerin yabancı dil yeterliliği konusunda çeşitli ölçütler sunarken, "turistin sağlı̆̆ı kapsamında bulunan kişiler ile milletlerarası sosyal güvenlik sözleşmesi ve sağlık alanında milletlerarası ikili işbirliği anlaşmaları gereği sağlı hizmeti almak için ülkemize gelen kişilere, yönlendirme ve rehberlik hizmetleri de sunulur" ifadesiyle, "uluslararası hasta rehberi" veya "uluslararası hasta hizmetleri sorumlusu" adlı kadrolarda görev yapan sözlü çevirmenlere, sağlık turizmi bağlamında yönlendirme ve rehberlik görevleri tanımlanmıştır. Duman’ın vurguladığı gibi;

[...] Ülkemizdeki en güncel sağllk mevzuatı bağlamında tercümanın bir "rehber" olarak değerlendirildiği ve salt sözlü çevirmen rolünden farklı olarak kültürlerarası arabuluculuk rolüne görev tanımı ve içeriği bakımından da yer verildiği görülmüştür. Uluslararası göç ile bağlantılı olarak verilen dilsel iletişim yardımcıllğ̆ için henüz arabuluculuk ifadesinin tercih edildiğini belirtmenin güç olduğu, bunun yerine sözlü çeviriyi ifade eden tercümanlık adlandırmasının kullanıldığı söylenebilir." (Duman, 2018:23)

Anket uygulanan sağlık çevirmenlerinin görünürlüğüne ilgili standartlardan başlayacak olursak, sağllk kuruluşlarının afet ve acil durumlara müdahale süreçlerine dair işleyiş ve prosedürlere bakıldığında, Aralık 2015 tarihli Hastane Afet ve Acil Durum Planı Hazırlama Kılavuzu9, sonrasında 2019 yılında yayınlanan Pandemik Influenza Ulusal Hazırlık Planı ${ }^{10}$, son olarak da COVID-19 (SARS-CoV-2 Enfeksiyonu) Rehberi ${ }^{11}$ başlıklı Kılavuz ve Planlar bulunmaktadır. Oluşturulan bu çerçevelerin kapsamına bakıldığında yalnızca Halk Sağlı̆̆ı Genel Müdürlüğü tarafından yayınlanan Pandemik Influenza Ulusal Hazırlık Planı'nın içeriğinde, kurumların ihtiyaç duyabileceği kaynaklar arasında çevirmene yer verildiği görülmektedir.

\footnotetext{
8 http://cdn.istanbul.edu.tr/FileHandler2.ashx?f=cevirmen-yeterlilikleri---toplum-cevirmeni---yayinlanan-taslak15.12.2018.pdf

https://www.saglik.gov.tr/TR,1789/hastane-afet-ve-acil-durum-plani-hap-hazirlama-kilavuzu.html

https://hsgm.saglik.gov.tr/tr/bulasicihastaliklar-haberler/ulusal-pandemi-hazirlik-plani.html

https://covid19bilgi.saglik.gov.tr/depo/rehberler/COVID-19_Rehberi.pdf?type=file
} 
Thinking about "New Normal" in healthcare interpreting and community interpreting in terms of COVID-19 conditions / F. Şan; R. Kahraman Duru (pp. 816-843)

T.C. Sağlık Bakanlığı bünyesinde "Sağlık Turizmi ve Turistin Sağlığı” kapsamında yurtdışından gelen hasta ve turistlere 7 gün 24 saat boyunca İngilizce, Arapça, Rusça ve Almanca dillerinde tercümanlık hizmeti verilmektedir.

Sunulan hizmetler aşağıda sıralanmaktadır:

- $\quad$ o 8502883838 Uluslararası Hasta Çağrı Merkezi, 4 dilde (İngilizce, Almanca, Arapça, Rusça) tercümanlık hizmeti verilmesi;

- Sağlık Turizmi ve Turistin Sağlığı kapsamında kamu hastanelerine gelen hastaların rapor, epikriz ve yurtdışından provizyon iş ve işlemlerine yabancı dilde destek verilmesi;

- Bakanlık merkez veya taşra teşkilatı telefon santrallerine yabancı dilde bir arama gelmesi halinde telekonferans sistemi ile görüşmelerde tercümanlık hizmeti verilmesi;

- 184 Sabim ve 112 Acil hattını yabancı hastaların yabancı dilde araması halinde 3’lü konferans sistemi ile tercümanlık hizmeti verilmesi.

\section{Sağlık çevirmenliğinde roller ve standartlar}

Sağlık çevirmenliği, diğer sözlü çeviri türleri ile karşılaştırmalı olarak ele alındığında, çalışma koşulları ve bağlamı itibari ile kendine has farklılıklar ve zorluklar içermektedir. Sağlık alanındaki çeviri faaliyetlerinde amaç, çevirinin tüm alanlarda olduğu gibi taraflar arasında bilgi aktarımını gerçekleştirerek, iletişimin sorunsuz işlemesini sağlamaktır. Ancak özellikle sağlık alanında iletişim aracılığı görevinin çoğu zaman dili bilen hasta yakınları ya da kurumda çalışan çok dilli personel tarafından üstlenilmesi, tedavi sürecinde aksaklıklara yol açabilmektedir. ${ }^{12}$

Hekime ilk başvuru örneğinden hareket edilecek olursa; hasta ve hekim arasında geçen konuşmanın temel amacı hastanın şikayetlerini açıklamasıyla hekimin teşhis koyabilmesidir. Hekim her ne kadar alanında uzman ve profesyonel olsa da, işini yapabilmesi hastanın şikayetlerini ifade edebilmesine bağlıdır. Bu bağlamda teşhis edilecek şikayetlere hasta sahipken, söz konusu şikayetleri hastalık belirtisi olarak değerlendirip, hastalık tanısı koyabilecek bilgiye sahip olan da hekimdir. Buna göre buradaki iletişimin sağlanması için ortak dilin oluşması gerekmektedir. Hekim ve hasta arasındaki bu diyalog soru-cevap şeklinde ilerlerken, hekim sorduğu sorularla işlevsel yanttlara ulaşabilmeyi amaçlar. Bundan hareketle de belirli bir hastalıktan şüpheleniliyorsa, soruların içinde daha spesifik ve belirleyici olabilecek alternatif yanıt seçeneklerine yer verebilir. Bunun farkında olmayan amatör çevirmen (örneğin dil bildiği için eşlik eden bir hasta yakını) hastaya bilgiyi aktarırken yönlendirici olabilmektedir. Ya da ek açıklamalar yaparak, ek sorular sorarak hastayı ve doktoru yanıltabilmesi de olasıdır. Üstelik oluşabilecek yanlış anlaşılmayı o an ne hastanın ne de hekimin fark etmemesi ihtimali de büyüktür (Bührig ve Meyer, 2009: 201).

Bu gibi sorunların tespiti için yapılan saha araştırmaları (bkz. Bührig ve Meyer 2009, Meyer 2019, Slapp 2004) tüm tarafların belirli düzeyde farkındalığa sahip olması gerektiğini ortaya koymaktadır. Bu bağlamda, hastanın dili bilmediği için çekingen davranmadan, ülkede yaşayan herkesle eşit hizmet alma hakkının olduğunu bilmesi, çevirmenin uzman bilgisi gerektiren bu tür görüşmelerde üstlendiği görevin sorumluluğu ile hareket etmesi ve hekimin iletişim aracı olarak çeviri etkinliğindeki dinamiklerin farkında olması gibi önemli hususlar sıralanabilir.

Buraya kadar sözü edilen araştırmalarda çevirmen, hasta ve hekim üçlüsünün donanımlarına, süreçteki işleyişlerine ya da aksaklıklara odaklanırken, yapılan araştırmaların bir sonraki aşamasında, çevirinin

12 Sağlık Hizmetlerinde sözlü çeviri konusunda detaylı bir çalışma Turan tarafindan da yapılmıştır. Bkz. Turan (2016) 
yapıldığı ortam, kurumsal standartlar ve yapılanmaların çeviri sürecinin eyleyicileri üzerindeki etkilerinin eleştirel bir yaklaşımla incelenmesine ihtiyaç duyulmaktadır. Bu ihtiyaçtan hareketle sahadaki işleyişi araştırmaya odaklanan bir çalışma da Sonja Pöllabauer tarafından yürütülmüştür. Pöllabauer "Community Interpreting bei Ämtern der Sozialverwaltung: Auf der Suche nach Verständigung” başlıklı çalışmasında, sosyal hizmet ve sağlık kurumlarındaki iletişim kalitesinin belirlenmesi konusunda gerçekleştirilen araştırma projesini tanıtmaktadır. İki kurum üzerinden yürütülen araştırmada, çeviri ihtiyacının belirlenmesi ve hangi ölçüde, nasıl karşllandığının ortaya koyulması amaçlanmaktadır. Araştırmacı, görüşme koşulları ve tarafların davranışları ile ilgili olarak elde ettiği bulguları eylem normları odağında ele alırken, Erich Prunč’un çeviri kültürü bağlamında ortaya koyduğu çeviri etiği kavramı açısından değerlendirmektedir. Araştırmanın sonuçları incelendiğinde, çeviri kültürü yaklaşımında Prunč’un çeviri sürecinde önemle vurguladığı işbirliği, sadakat/güvenilirlik ve şeffaflık ilkelerinin, söz konusu kurumlarda işlerlik kazanmadığı görülmüştür. Buna göre görev ve sorumlulukların paylaşımı üzerine yapılanmış bir işbirliğinden söz etmek imkansız olduğu gibi, karşllıklı beklentilerin gözetildiği sadakat ya da her türlü eylemin izlenebilirliğine imkan veren şeffaflık ilkesinden herhangi bir aşamada söz etmek mümkün değildir. Araştırma sırasında gözlemlenen, çeviri kültürünün demokratik, adaletli, verimli olmaktan çok uzak kaldığı yönündedir. Bununla birlikte araştırmaya konu olan kurumlar, çeviri koşullarının araştırılması sonucu, sorunsal olarak nitelendirilebilecek noktalarda, kaynak eksikliği ve zaman darlığı gibi gerekçeleri öne sürerek oldukça dikkat çekici bir şekilde işleyişlerini kusursuz gösterme çabasına girmektedir. Pöllabauer, sorunların çözümü ve işleyişin iyileştirilmesi yönündeki çalışmalara gerek görülmemesi ile ilgili tutumun, çoğunluk kültürünü daha fazla önemseyen, ideolojik bir bakış açısının ürünü olup olmadığının da irdelenmesi gereken bir husus olduğuna işaret etmektedir. (Pöllabauer, 2010: 373)

Pöllabauer'in araştırması, sürecin mikro yapıların incelenmesine ek olarak makro ölçekteki kurumlar ve standartlar düzeyinde de sorgulanmasının önemini ortaya koymuştur. Bir çeviri dizgesi içinde yapılandırılan çeviri ve çevirmenlik standartları, çalışma ilkeleri ya da çerçeveleri, yukarıda sayılan ilkelerin varlığının sorgulanabileceği en somut kaynaklar olarak karşımıza çıkmaktadır.

Çevirmen yeterliliklerinin yanında, çevirmenin iletişim halinde olduğu kişi ve koşullar gibi öğeler de çeviri kalitesinde ve çıktısında belirleyici olmaktadır. Sağlık çevirmenliği, psikolojik olarak dayanıklılık ve uyumun en çok gerektiği, çeviri ortamının yüksek oranda hassasiyet ve buna bağlı stresi barındırdığı çalışma koşullarında gerçekleştirilmektedir. Bu koşullara göre ihtiyacın yoğun, acil ve yaşamsal olması nedeniyle belli mesleki yeterlilikleri ve standartlaşmayı gerektirmektedir. Bu anlamda Türkiye'de 15.12. 2018 tarihli Mesleki Yeterlilik Kurumu Ulusal Yeterlilik Çalışmaları başlığı altında Toplum Çevirmenliği Yeterlilikleri konusunda oluşturulan taslak standartlar önemli bir çerçeve olarak dikkate alınabilir. $\mathrm{Bu}$ belgede; "Alternatif 3-A1, A2 B1, B2 birimlerini Sağhk bağlamında başararak mesleki yeterlilik belgesi sahibi olan kişiler Toplum Çevirmeni (Sağllk) mesleki yeterliliğine sahip kişilerdir” ifadesi ile yeterliliğin kapsamı tanımlanırken, dil ve kültür bilgisi, yazılı ve sözlü çeviri stratejileri ile sözlü çeviri performans stratejileri gibi çevirmenin sahip olması ve sergilemesi gereken yeterlilikler siralanmaktadır.

Bu kapsamda çevirmenleri amatör ve profesyonel olarak iki ana grupta düşünürsek, akla gelebilecek farklı insan kaynakları şunlar olabilir: birinci grupta iki dil bilen sağllk personeli, hastane personeli, hasta yakını ya da çocukları ile diğer dil bilen hastalardan oluşan amatör çevirmenler; ikinci grupta ise yabancı dil yetkinliği gelişmiş, çeviri konusunda eğitimli ve birikimli, kurum içinde çeviri / uluslararası 
Thinking about "New Normal" in healthcare interpreting and community interpreting in terms of COVID-19 conditions / F. Şan; R. Kahraman Duru (pp. 816-843)

iletişim işiyle görevli olan ya da kurum dışından çeviri hizmeti sağlama şeklinde sürece dahil olan profesyonel çevirmenler. ${ }^{13}$

Diğer yandan ülkelerarası karşılaştırmalı araştırma sonuçlarında da ortaya konulduğu üzere, bir ülke içindeki yapılanma hangi standartta ya da profesyonellik seviyesinde olursa olsun, yine de herhangi bir formasyona sahip olmayan çevirmenlerle çalışmanın kaçınılmaz olduğu, her geçen gün daha da belirgin bir gerçeklik olarak ortaya çımaktadır. Bu nedenle bu kişileri de bir şekilde formasyon kazanmaları ve temel çevirmenlik becerilerini edinmeleri için desteklemek önemli bir nokta olarak karşımıza çıkarken, aynı zamanda bu çevirmenlerle çalışan sağlık personelinin de çevirmenle çalışma konusunda hizmet içi eğitim seminerleri almaları sağlıkla ilgili çeviri sürecinin sağlıklı akmasına olanak verecektir (B. Schouten, J. Ross, R. Zendedel and L. Meeuwesen, 2014).

Çevirmenin pozisyonu, statüsü, saygınlık, dayanışma, cinsiyet, yaş, etnik kimlik ve aidiyet duygusu, uyruğu ve sosyo ekonomik durumu, kültürel ve sosyal normlar, çeviri süreci açısından belirleyicidir. Angelelli’nin görünürlük modeline göre çevirmen iletişimi kolaylaştıran, görüşmenin yönünü önemli ölçüde etkileyen görünürlüğü ile önemli bir noktada konumlanır (Angelelli 2004). Bu durumda aşağıdaki koşulların çevirmenin çeviri sürecindeki görünürlüğünü ve kolaylaştırıcılı̆̆ını etkileyebilmektedir:

- Hastanın hayatının ya da sağlık durumunun, çevirmenin performansına ya da yetkinliğine bağlı olduğu bir ortamın söz konusu olması,

- Hastanın bedensel ya da ruhsal durumu,

- Sağlık çalışanlarının, hastaların ve ailelerinin çevirmenlerle çalışma alışkanlıkları,

- Terminoloji kullanımı,

- Kültürel engeller

- Sağlık personelinin dil kullanımı,

- Gizlilik (mahremiyet)

- Duygusal tepkilerin görüşmeye olumsuz yönde yansıması,

- Hekimin hastaya yardımcı olmada başarılı olamaması,

- Çalışma ortamındaki koşulların duyma ya da iletişim kurma kapasitesini azaltması,

- Çalışma ortamında sağlık çalışanları için gerekli hijyen ve koruma koşullarının bulunduğu ve bulunmadığı haller.

Toplum çevirmenliğinin alt alanlarının belirlenmesi ve standartlaştırılması üzerine çalışılırken, diğer yanda toplumsal yapılar her geçen gün dinamik bir şekilde değişmektedir. Bugün karşılaşılan Covid-19 pandemisi gibi afet/kriz durumlarında, iletişim üçgenindeki herkes risk altındadır. Bu durum ezberleri bozarak, tüm kavramsal yapıları yeniden sorgulamayı ve "yeni normal” yaklaşımı ile yeniden tanımlama ihtiyacını ortaya koymaktadır.

\section{Covid-19 pandemi sürecinin çeviri hizmetlerine etkisi}

Geçtiğimiz yıl sonu itibari ile Çin'den yayılarak dünyayı tehdit etmeye başlayan COVİ-19, Şubat ayına geldiğimizde Türkiye'de de kongre ve toplantı sektöründe erteleme ve iptaller üzerinden sözlü çeviri alanındaki etkisini göstermiştir. 11 Mart 2020 itibari ile Dünya Sağlık Örgütü'nün yeni koronavirüse

Sağlık çevirmeninin rolü ve etik yaklaşımlar konusunda bir çalışma da Şener ve Kıncal tarafından yapılmıştır. Bkz. Şener ve Kincal (2019). 
bağlı pandemi ilan etmesiyle, her türlü toplantı, etkinlik, fuar ve organizasyon, her ülkede farklı uygulamalarla durma noktasına geldi.

Çeviri yapılan iş konuları arasında eğitim, sağlık, e-ticaret, medya ve iletişim, kişisel bakım, ekonomi, finans ve hukuk alanları yükseliş kaydederken, yazılım, kamu hizmetleri, gayrimenkul gibi alanlar yerlerini korumakta, ancak seyahat ve konaklama, konferanslar, üretim, spor, inşaat, emlak ve istihdam alanlarında düşüş ve işi kaybı yaşanmaktadır. ${ }^{14}$

Toplantı, fuar ve etkinlik organizasyonu firmalarının en önemli hizmet sağlayıcılarından çoğu serbest olarak faaliyet gösteren çevirmenler de bu süreçlerden fazlasıyla olumsuz etkilendiler. Çevirmenler bu süre içinde herhangi bir destek ve güvence kapsamında yer alamadıkları gibi, sektörde en 2020'nin Eylül ayından önce bir normalleşme sürecinin başlaması oldukça uzak bir olasılıktır. Buna ek olarak Çevirmenler sosyal medya ortamlarından, uzaktan çeviri yöntemleri ve şartları, fiyatların düşürülmesi yönünde gelecek tekliflere karşı dirençli olma noktasında çağrı ve bilgilendirme ile dayanışma içinde bulunmaya çalışmıştır'15.

Uzaktan çeviri yöntemleri, Webinar ve benzeri teknolojik araçların kullanılması ile birlikte, kabin standartlarından çalışma koşullarına, biçimlerine ve kullanılan teknolojilere kadar pek çok alanda "yeni normal” standartları yapılandırılmaya ve yaygın olarak kullanılması sağlanmaya çalışılmaktadır.

Ayrıca mesleki güç birliğine ve çevirmenlerin de korunması gereken hakları olduğuna vurgu yapmak adına, dünyanın çeviri alanındaki üç önemli sivil toplum kuruluşu (International Association of Conference Interpreters - AIIC, World Association of Sign Language Interpreters - WASLI ve International Federation of Translators - FIT) bir araya gelerek ortak çağrılarda bulunmakta, aynı zamanda yeni normalin standartlarını da tanımlamaktadır ${ }^{16}$.

Covid-19 kuşkusuz ki en çok sağlık alanındaki çeviri hizmetlerini etkilemiştir ve buna göre bu etkilerin yansımalarının nasıl olduğu somutlaştırılması gereken önemli bir husustur.

\subsection{Araştırmanın kapsamı ve yöntemi}

Toplum çevirmenliğinin bir alt alanı olan, artan göç hareketliliği ve sağllk turizmi ile birlikte sağllk hizmeti veren kurumların içinde görünürlük kazanan sağllk çevirmenliği, bu araştırmanın evrenini oluşturmaktadır. Bu kapsamda, COVID-19 sürecinde çevirmenlerin, nasıl ve nerede konumlandıklarına dair bir süreç analizi ve durum tespiti yapılması amacıyla sağlı sektöründe görev alan çevirmenler için bir anket sunularak, yeni normal düzende üzerinde durulması gereken önemli noktaların ortaya çıkarılması hedeflenmiştir.

Pandemi esnasında öncelikli ihtiyaç alanı olan sağlık hizmetlerinde görev alan çevirmenler, araştırmanın örneklemi olarak belirlenmiştir. Çevirmenlerin çeviri süreçleri soruşturularak genel bir üst bakış sağlanması amaçlanmıştır. Bu yaklaşımdan hareketle, "COVID-19 (Yeni Koronavirüs) VAKALARINDAKİ ÇEVIRİ HIZMETLERİ” başlı̆̆ ile oluşturulan anketin hedef kitlesi, sağllk kurumlarında, toplum merkezlerinin sağllk hizmetlerinde görev alan çevirmenlerle, kurum dışı uzaktan çeviri desteği veren çevirmenleri kapsayacak şekilde belirlenmiştir. Çevirmen kitlesinin, erişilebilirliği

14 https://www.nimdzi.com/covid-19-in-language-services-early-considerations/

15 https://euatc.org/industry-hot-topics/translation-company-security-measures-need-to-be-strengthened-during-thecovid-19-crisis/

16 https://aiic.net/page/8947/appeal-to-authorities-by-aiic-fit-and-wasli/lang/1

https://ataspd.org/2020/04/29/covid-19-pandemic-impact-and-effects-on-us-ti-professionals/ 
Thinking about "New Normal" in healthcare interpreting and community interpreting in terms of COVID-19 conditions / F. Şan; R. Kahraman Duru (pp. 816-843)

ve faaliyet alanları gözetilerek, sosyal medya platformları, mail grupları, kurum ve kişiler vasıtasıyla kendileri ile irtibata geçilmiştir.

Anket çoktan seçmeli ve onay kutulu olarak hazırlanmıştır; kısa açıklamalar şeklinde yanıtlanacak 22 sorudan oluşmaktadır ve isim belirtme zorunluluğu bulunmamaktadır. Yönlendirici veya kısıtlayıcı olmamak adına, çoktan seçmeli sorulara "diğer" seçeneği de eklenmiştir. Bu sayede ankette sunulan seçeneklerin dışındaki görüşlere de ulaşma imkânı doğmuştur. Anket çeşitli platformlarda paylaşılmış ve sağlık alanında kurum içi ya da dışından çeviri hizmeti veren çevirmenlerin doldurması istenmiştir. Yapılan anketle aşağıdaki ana sorulara yanıt aranmıştır:

- Mevcut koşullarda sağlık alanında sözlü çeviri hizmeti veren çevirmenlerin profili nedir?

- Çevirmenler pandemi koşullarında nasıl çalışıyor?

- Çevirmenlerin çalışma koşulları, standartları neler?

- Çevirmenlere sunulan imkanlar neler?

- Çevirmen mevcut koşullardan nasıl etkileniyor?

- Çevirmenlerin mevcut koşullarla ilgili görüşleri nedir?

\subsection{Araştırmanın bulguları ve değerlendirme}

Anket sonuçları dört ana başlık altında incelenecektir: (1) çevirmenlerin profili, (2) pandeminin genel etkileri ve çalışma koşulları, (3) çevirmen için zorlayıcı kişisel ve çevresel koşullar ve etkileri. Bunlara ek olarak, (4) çevirmenlerin koşulların iyileştirilmesi ve genel düşüncesi ile ilgili görüşlerine başvurulmuştur. Değerlendirmeye geçmeden önce ana başlıklar ve alt başlıkların verilmesi üst bakış sunması bakımından yerinde olacaktır.

Çevirmenlerin Profili

- Cinsiyet

- Yaş

- Bölgesel dağılım

- İllere göre dağılım

- Çeviri dilleri

- Görev yeri

Pandeminin Genel Etkileri ve Çalışma Koşulları

- Pandemi Etkileri

- Pandemi Süreci Çalışma Saatleri

- Çalışma Ücreti

- Çalışma Standartları

- İş Yeri Koşulları

- İş Yeri Çalışma Kuralları

- Desteklerden Yararlanma

- Alınan Tedbirler

Çevirmen için Zorlayıcı Kişisel ve Çevresel Koşullar ve Etkileri

- Kişisel Koşullar ve Etkileri

- Kişisel Koşullar

- Pandeminin Çevirmen üzerindeki genel etkisi

- Pandeminin Çevirmen üzerindeki psikolojik etkisi

- Çevresel Koşullar ve Etkileri

Çevirmen Görüşleri

- Alınan Tedbirler

- İş Yerinde Zorlayıı Unsurlar

- Destekleyici ve Koruyucu Çalışmalar 
- Koşulların İyileştirilmesi

- Çevirmenlerin Genel Görüşleri

Söz konusu araştırma sorularının yanıtlanabilmesi için oluşturulan anket ${ }^{17} 75$ çevirmen tarafından doldurulmuştur. Anketi yantlayanlardan ikisi, Öğretim Üyesi / Görevlisi olmaları ve sahada çalışmamaları nedeniyle anketin hedef kitlesinden ayrılmaktadır. $\mathrm{Bu}$ sebeple bu katılımcılar araştırmanın dışında tutulmuştur.

\subsection{1. Çevirmenlerin profili}

Çevirmenlerin profilini belirlemeye dönük sorular, cinsiyet, yaş, il ve bölgesel dağllıma ek olarak çevirmenlerin çeviri yaptı̆̆ dilleri ve görev yeri konusundaki bilgilerini içermektedir. Bu çerçevede sorulan sorulara alınan yanıtlar aşağıda sunulmuştur.

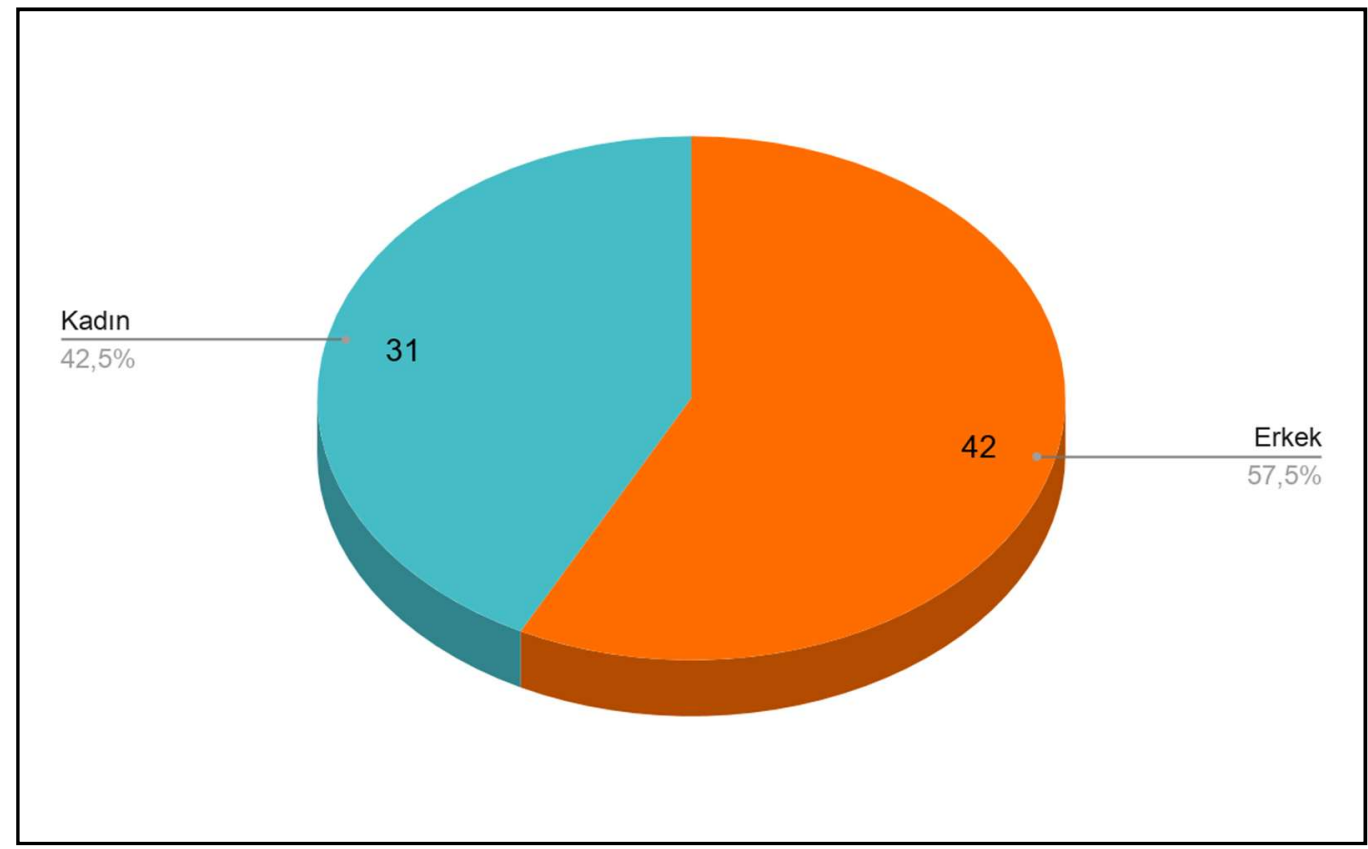

Grafik 1: Cinsiyet

Grafikten de görüleceği gibi anketi dolduranların \%42,5'si kadınlardan ve \%57,5 de erkeklerden oluşmaktadır. Kadın ve erkek olarak ayrıştırma, araştırma grubunun koşullara bağlı etkilendikleri durumlara dahilinde cinsiyete bağlı farklılıklar olabileceğini ortaya koymaktadır.

$\mathrm{Bu}$ farklılıklar çevirmenler tarafından hamile olma, evde küçük çocuğunu bırakarak işe gitmek durumunda kalma şeklinde fiziksel durumlar ve toplumsal roller kaynaklı çeviri süreci ve çevirmenin ruhsal durumu ve dolayısı ile çeviri performansına olumlu olumsuz olarak yansıyabilmektedir.

Özellikle toplum çevirmenliğinin hastane, psikolog görüşmeleri, karakol ve mahkeme türlerinin uygulama alanlarında çevirmenin cinsiyeti, çeviri hizmeti alan taraf açısından güven ve rahatlık ya da çeviri sürecinde kolaylaştırıcılık etkisi yaratabileceği gibi, aksi durumlarda çeviri sürecinin tamamlanamaması gibi sonuçlara da neden olabilmektedir. Bu noktada çevirmenin cinsiyeti çeviri 
Thinking about "New Normal" in healthcare interpreting and community interpreting in terms of COVID-19 conditions / F. Şan; R. Kahraman Duru (pp. 816-843)

sürecinde önemli bir belirleyici unsur olarak görülebilir. Anketin sonraki soruları bu konulara dair verilen geri bildirimlerle daha net hale gelmektedir.

Anketi dolduranların iller ve bölgeler bazında dağılımı aşağıdaki iki grafikte gösterilmiştir:

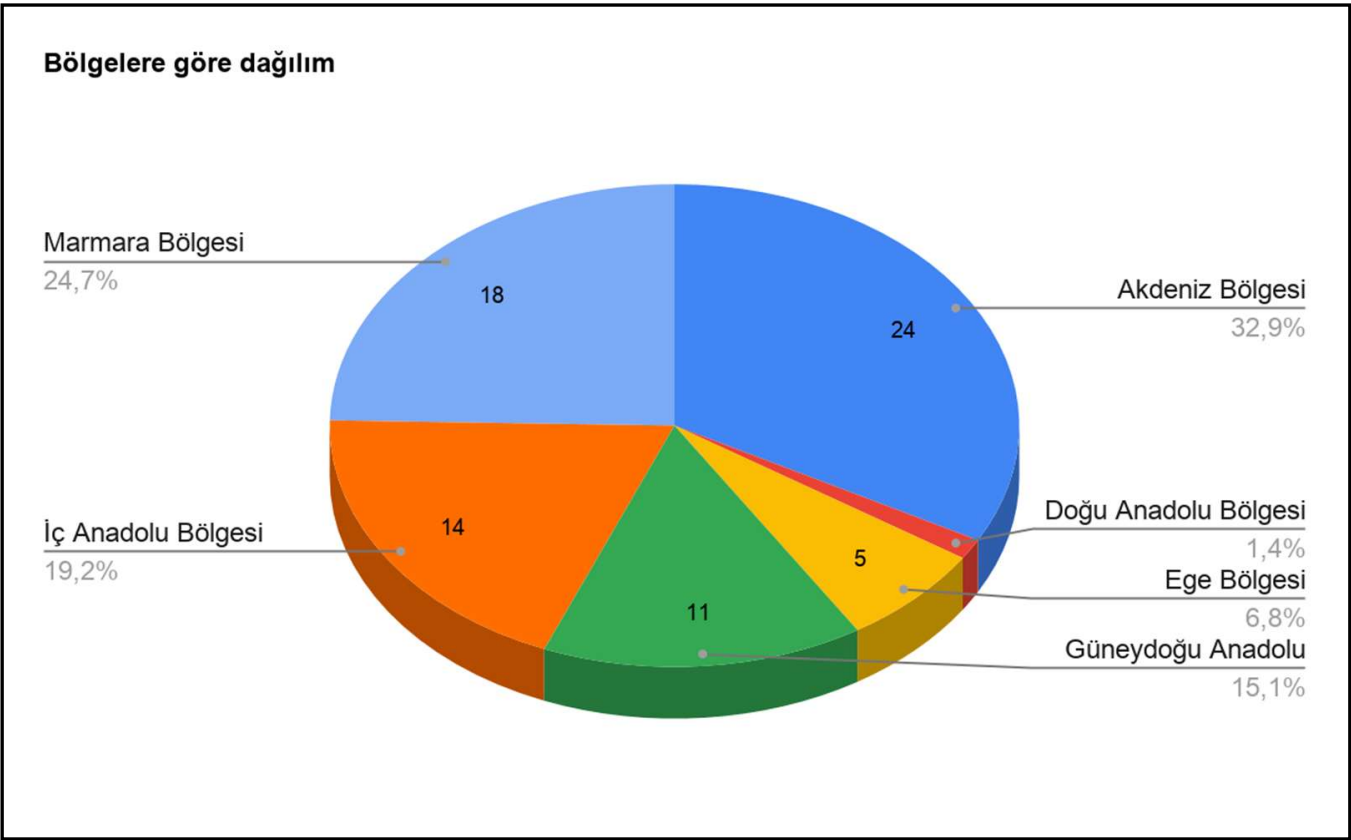

Grafik 2: Bölgesel dağılım

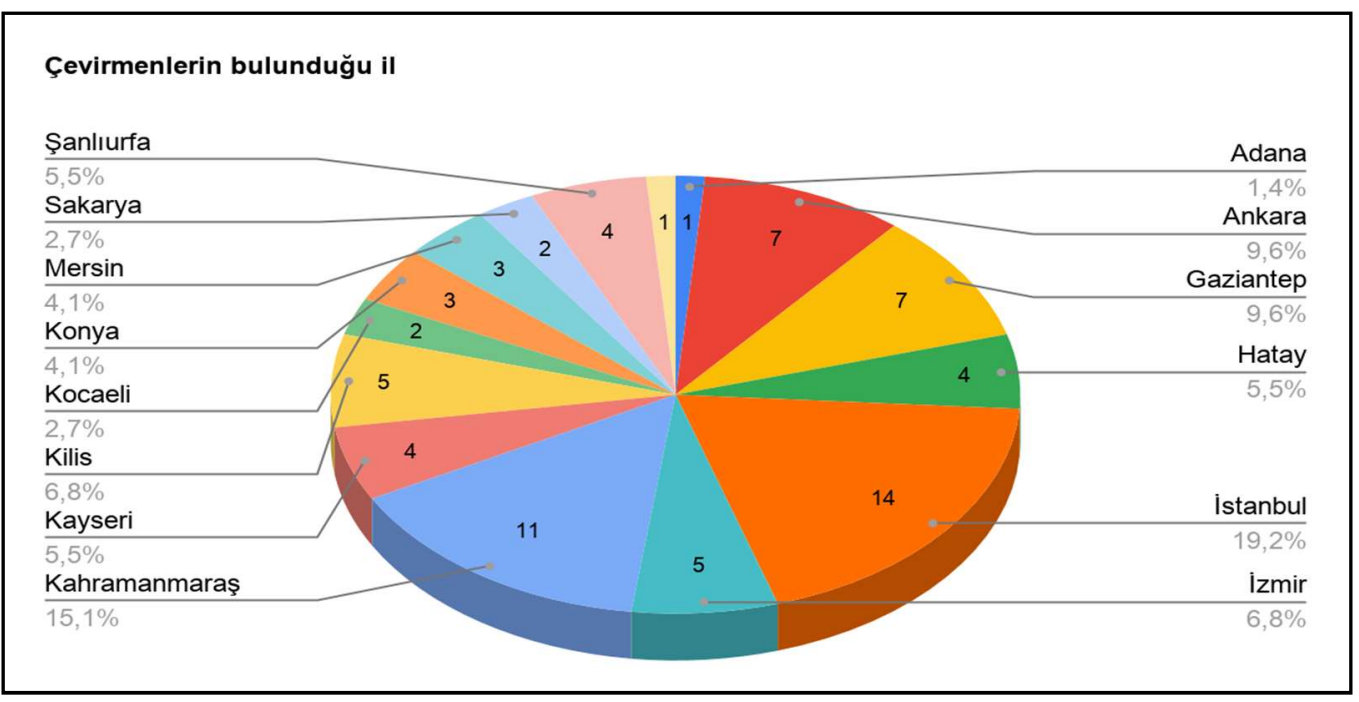

Grafik 3: İllere göre dağılım

Anketi dolduranların başta İstanbul, Kahramanmaraş, Ankara, Gaziantep, Kilis ve İzmir olmak üzere 15 farklı ilde bulunduğu görülmektedir. Ankette, özellikle Türkiye'deki mültecilerin yoğun olduğu bölgelerde Covid-19 sürecinde sağlık alanında çeviri hizmeti veren çevirmenler ağırlıklı olmak üzere, sahada sağlık hizmetleri alanında görev yapan çevirmenlerin mevcut durumuna ilişkin bir üst bakış edinmek hedeflenmiştir. 


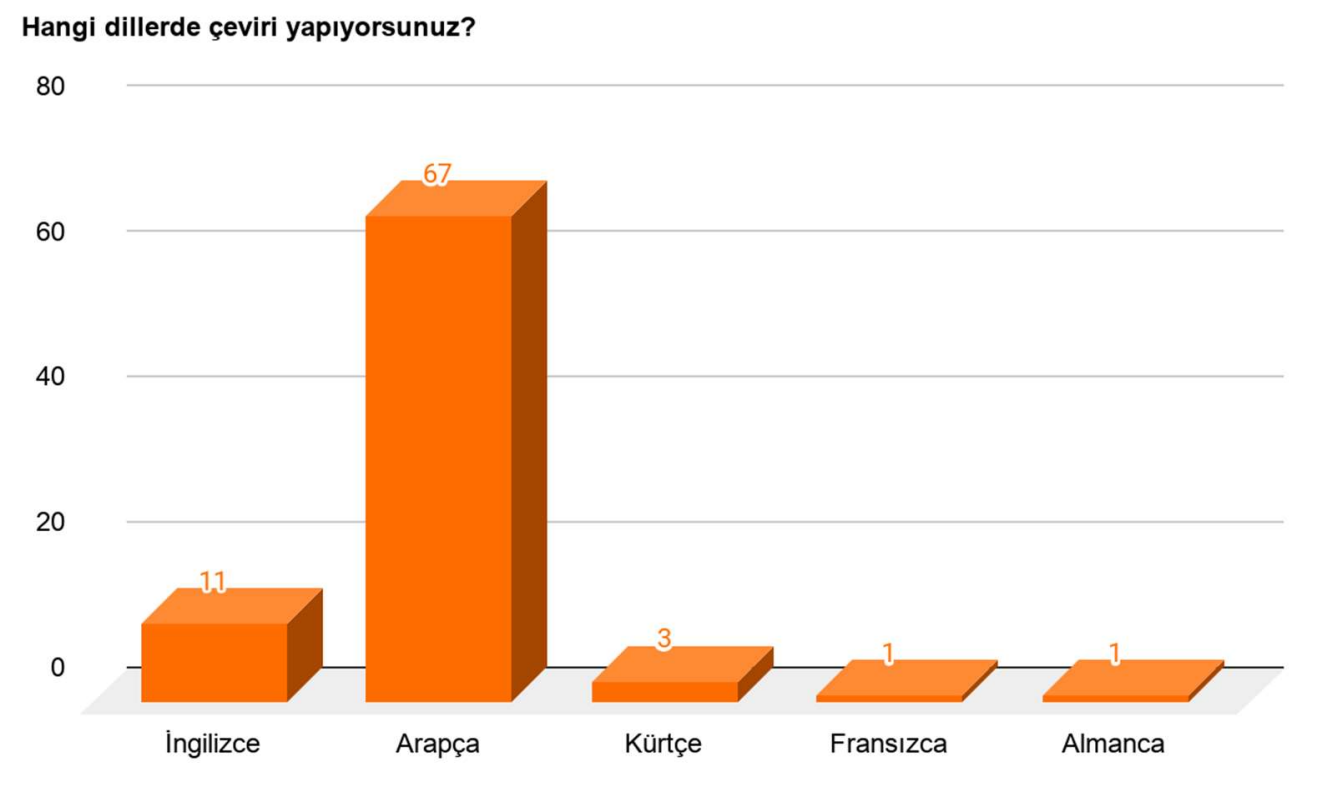

Grafik 4: Çeviri dilleri

Anketi dolduranların büyük çoğunluğu Arapça çevirmenlik yapmaktadır. Grafikten de görülebileceği gibi bu sayı 67'dir. Oran olarak hesaplandığında ise anketi dolduran saha çalışanlarının \%8o,7'lik oldukça büyük bir grubunun Arapça çevirmenlerinden oluştuğu söylenebilir.

Bunun nedeni, çeviri ihtiyacının, Türkiye’ye 2011 yılında başlayan ve giderek artan göçmen nüfusunun yoğunluklu olarak Suriye başta olmak üzere, Ortadoğu ülkelerinden zorunlu olarak göç etmiş kitlelerle oluşan demografik yapılanma olarak ifade edilebilir (Erdoğan, 2015).

Arapçayı \%13,3 oranıla İngilizce ve \%3,6 oranıyla Kürtçe takip etmektedir.

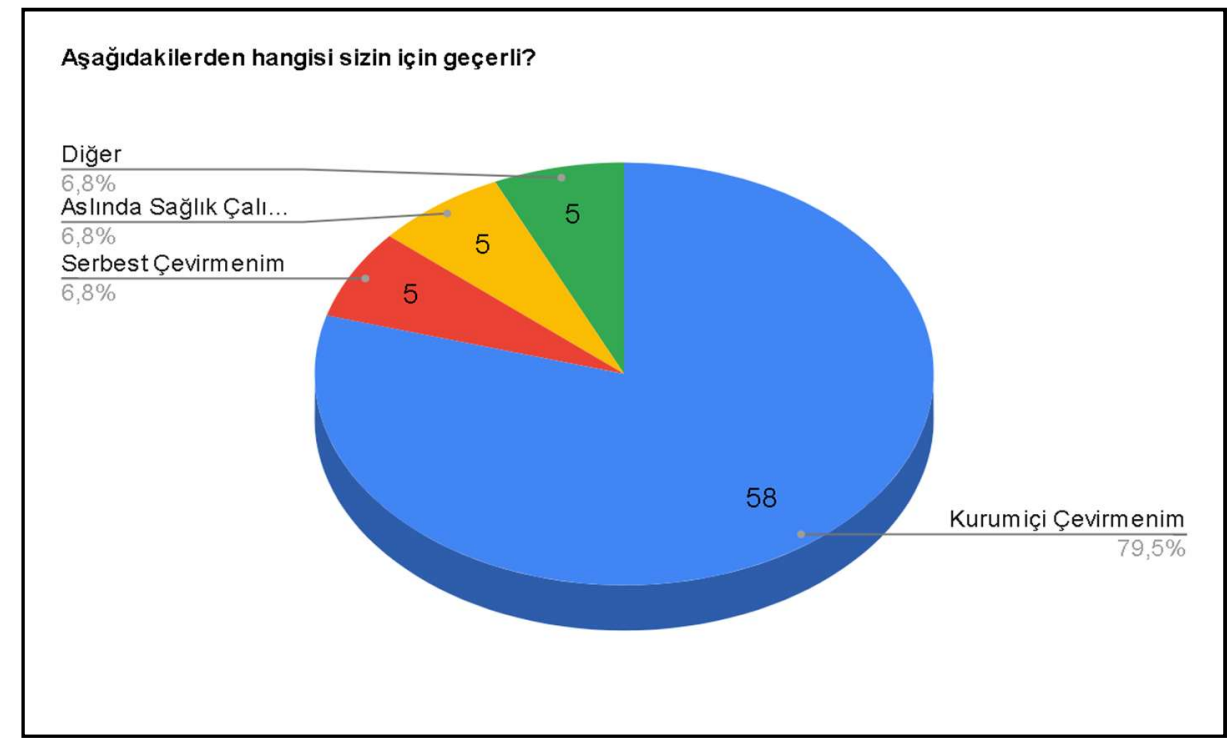

Grafik 5: Görev yeri ve tanımı 
Thinking about "New Normal" in healthcare interpreting and community interpreting in terms of COVID-19 conditions / F. Şan; R. Kahraman Duru (pp. 816-843)

Kişilerin nerede görev yaptıkları ile ilgili soruya verilen yanıtlar incelendiğinde, \%79,5 oranıyla büyük çoğunluğun kurum içi çevirmen olduğu anlaşılmıştır. Sağllk çalışanı olup bu süreçte çevirmenlik yapanların ve serbest çevirmen olanların sayısı oldukça azdır. Bu sonuca göre, bu araştırmada anketin daha çok kurumlarda ve toplum merkezinde görev alan çevirmenlere ulaştığını söylemek yanlış olmayacaktır. Bu bağlamda bulguların sahayı birebir yansıttığı çıkarımında bulunmamak gerekir, nitekim akraba ve tanıdıklarla ya da ücreti karşılığında tavsiye üzerine eşlik etmesi için çağrılan kişilerle iletişim sorununu aşan önemli bir kesimin olduğu da bilinmektedir. Buna göre elde edilen bulguları kesin bir yargı şeklinde genellemek yerine, bu araştırmanın kısıtları çerçevesinde değerlendirmek gerekir.

Buradaki bulgular bu çalışmanın ulaşılabilirliği ile sınırlıdır. Bu bağlamda Sağlık Bakanlığı ile birlikte yapılacak geniş çaplı bir araştırma prosedürler ve saha uygulamaları hakkında daha fazla bilgiye ulaşılmasına olanak sağlayacaktır. Ancak bu çalışmanın sınırları dışında kalması nedeniyle, bu konuyu "yeni normal" şartlara geçtikten sonra başka bir araştırmada ele alıp incelemek daha doğru olacaktır.

Soruya verilen yanıtlarda sayıları çok az da olsa sivil toplum kuruluşunda, Toplum Merkezinde kurum içi çevirmenim gibi açıklamalar yapanlar da olmuştur. Bununla birlikte öğrenci olup sahada çevirmenlik desteği veren kişilerin olduğu da görülmüştür.

\subsubsection{Pandeminin genel etkileri ve çalışma koşulları}

Pandeminin genel etkilerini ve çalışma koşullarını belirlemeye dönük sorular, Pandemi Etkileri, Pandemi Süreci Çalışma Saatleri, Çalışma Ücreti, Çalışma Standartları, İş Yeri Koşulları, İşyeri Çalışma Kuralları, Desteklerden Yararlanma, Alınan Tedbirler konusundaki bilgileri içermektedir. Bu çerçevede sorulan sorulara alınan yanıtlar aşağıda sunulmuştur.

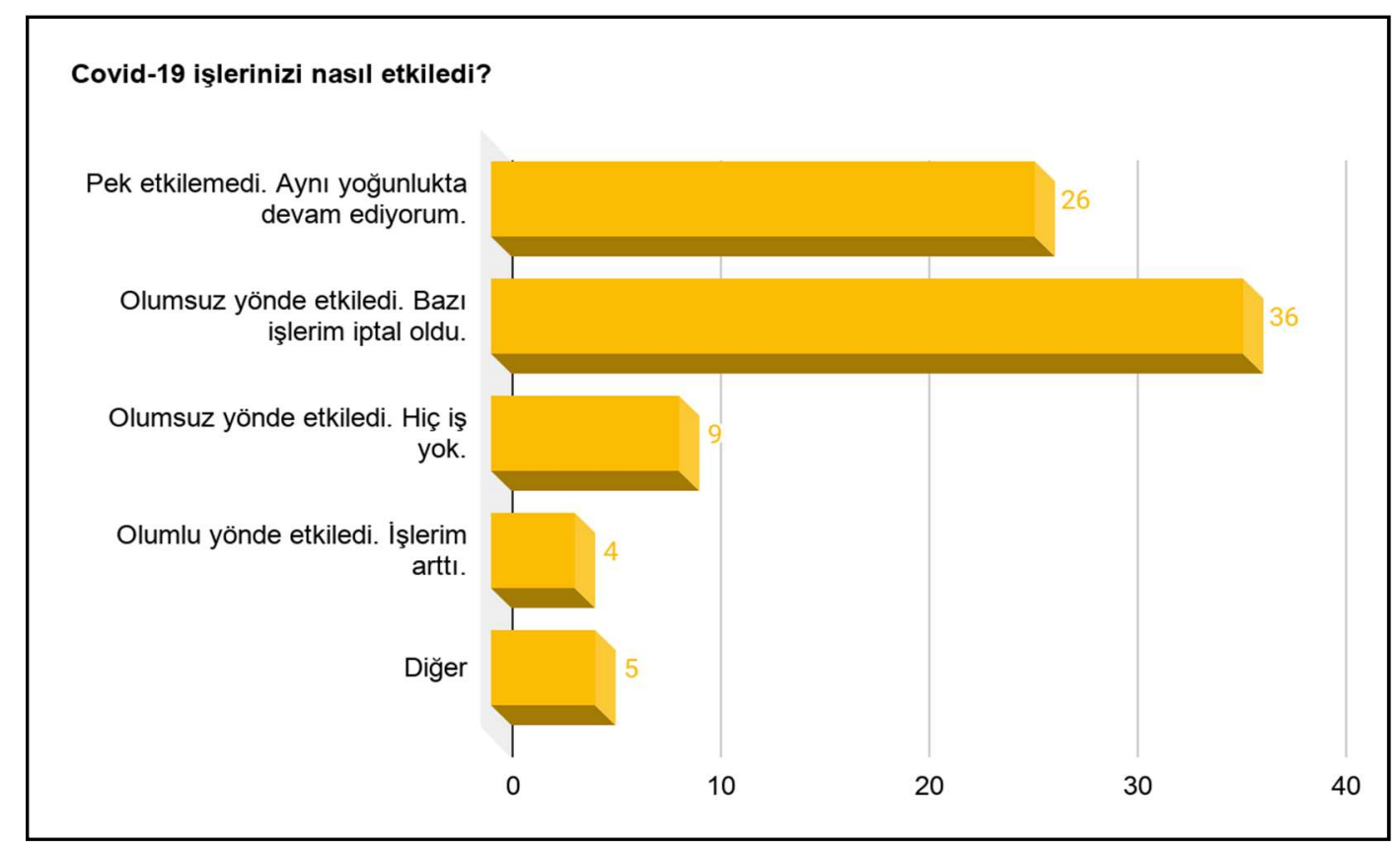

Grafik 6: Pandemi etkileri

Bu soruda amaç çeviri işlerinin Covid-19'dan nasıl etkilendiğini ortaya koyabilmektir. Bu amaçla oluşturulan şıklarda birden fazla işaretleme yapma olanağı verilmiştir. Grafikten hareketle Covid-19'un 
çevirmenlerin çoğunluğunu olumsuz yönde etkilediği çıkarımında bulunmak olanaklıdır. Olumsuz etkilenenlerden \%45’inin bazı işlerinin iptal edildiği yönünde ve \%11,3 çevirmenin ise hiç iş alamadığı yönünde yanıt verdiği görülmektedir. Buna göre mevcut durumdan olumsuz yönde etkilenenlerin oranı $\% 56,25$ 'tir.

Öte yandan mevcut durumdan işleri etkilenmeyen çevirmenlerin de oranı oldukça fazladır. Anket dolduran çevirmenlerin \%32,5’i etkilenmediği ve işlerinin aynı yoğunlukta devam ettiği yanıtını vermiş̧ir. Buna karşın işlerinin arttığını ve bu bağlamda olumlu etkilendiğini ifade edenlerin oranı \%5’tir. Diğerleri olarak kalan azınlıktaki grup ise aslında değişmekte olan "yeni normal” düzendeki çalışma koşullarına dair minik de olsa ipuçları vermektedir. Esnek çalışmaya geçtikleri için yoğunluklarının azaldığını, evden çalıştığını, iş yoğunluğunun değişmekle birlikte farklı bir yöne evrildiğini söyleyenler ile sağlık çalışanları ve psikologlar ile semptom taraması yaptıklarını ifade edenler de vardır. Buna göre “diğer” şıkkı üzerinden gelen yanıtlar oldukça çeşitlilik göstermektedir.

Covid-19'un Türkiye'de görüldüğünden beri günde kaç saat çeviri yapıyorsunuz?

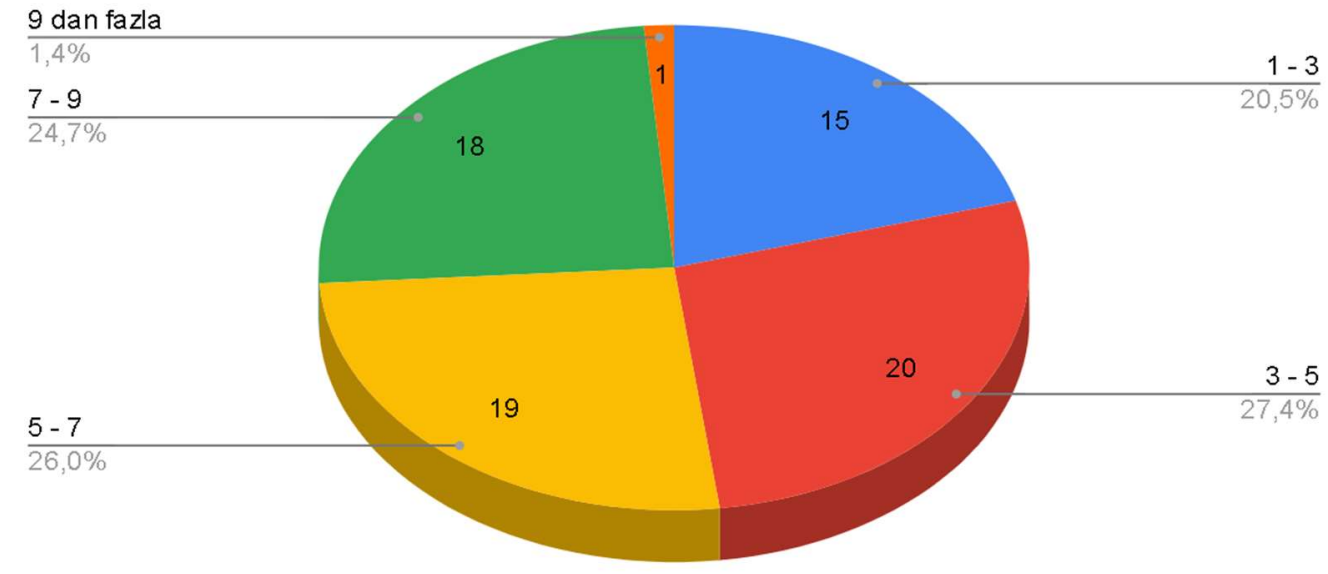

Grafik 7: Pandemi süreci çalışma saatleri

Bu sürecin çeviri ve çevirmen mesaisine yansımalarının ne olduğu sorgulandığında yukarıdaki tablo ile karşılaşılmaktadır. Çevirmenlerin \%27,4'ü 3-5 saatlik mesailer ile çalışırlarken, \%19'u 5-7 saat, \%18'i normali aşan eşikte 7-9 saat ve \%1,4'ü de 9 saatten fazla mesai yaptıklarını bildirmişlerdir. 9 saatten fazla çalıştığını açıklayan bir çevirmen haricinde, çalışma saatlerinde yaklaşık olarak eşit bir dağılım görülmektedir. Buna göre normal düzende SGK tarafından tanımlanmış 7,5 saatlik çalışma süresi ile sözlü çeviri standartlarında tanımlanmış 6 saatlik çalışma süresinin pandemi sürecinde çeşitlilik gösterdiği söylenebilir. Bu çeşitliliğin nedenleri de farklı olabilir; pandemi koşullarında etkilenme boyutunu aza indirgemek amacıyla azaltılan personel ve dönüşümlü çalışmanın esas alınmış olunması, azalan mesai saatlerinin açıklaması olarak düşünülebileceği gibi, buna mukabil artan mesai saatleri de vakaların yoğunluğu ile birlikte yetersiz kalan kurum içi personelin daha da yoğunluklu olarak çalışmasının zorunlu olduğu hallerin de söz konusu olabileceği için net bir çıarımda bulunulamayacağı söylenebilir. Bu çalışma saatleri ile ilgili dağılımı hangi çevirmenlerin işaretlediğine bakıldığında, sağlık çalışanlarının ortalama 5 saat, serbest çevirmenlerin ortalama 3 saat ve ağırlıklı olarak toplum 
Thinking about "New Normal" in healthcare interpreting and community interpreting in terms of COVID-19 conditions / F. Şan; R. Kahraman Duru (pp. 816-843)

merkezinde çalıştıkları düşünülen kurum çevirmenlerinin de ortalama 5,5 saat çalıştığı çapraz bir değerlendirme ile anket sonuçlarından görülmektedir. Ancak sonuçların çeşitlilik göstermesi, çalışma süreleri konusunda net bir çıkarımda bulunmanın çok da mümkün olmadığını ortaya koymaktadır.

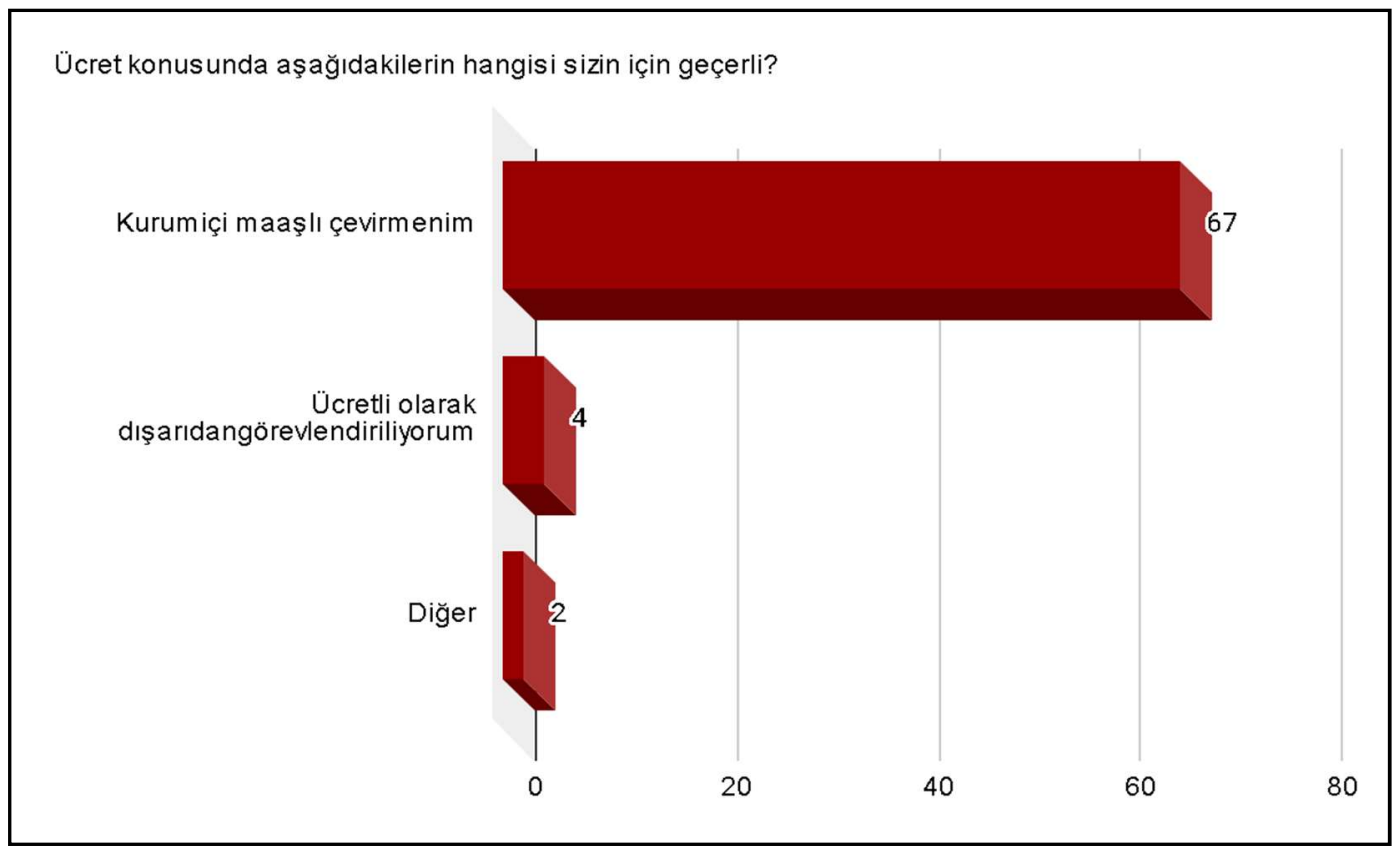

Grafik 8: Çalışma ücreti

Ücretlendirme konusunda grafikte net bir ağırlık görünmektedir. Sonucun bu yönde çıkması anketin ulaştığı kitle ile doğrudan ilintilidir elbette. Buna göre kurum içi çevirmenler yoğunlukta olduğu için (anketi dolduranların \%91,3'ü) hizmet bedelleriyle ilgili olarak standart sözleşmelerin bağlayıcılı̆̆ının söz konusu olduğu söylenebilir. Kurumlar bu süreçte az sayıda ücretli ve dışarıdan gönüllü desteğine ihtiyaç duymuştur. Bu soruyu duruma göre ya ücretli olarak dışarıdan görevlendirildiğini ya da gönüllü olarak ücretsiz çeviri hizmeti verdiğini açıklayarak yanıtlayan da olmuştur. 
Sağlık kuruluşu sizden hizmet alırken herhangi bir sözleşme imzalatıyor mu?

Sağlık kurulusu benden hizmet almıyor / Sağlık kuruluşuna hizmet vermiyorum
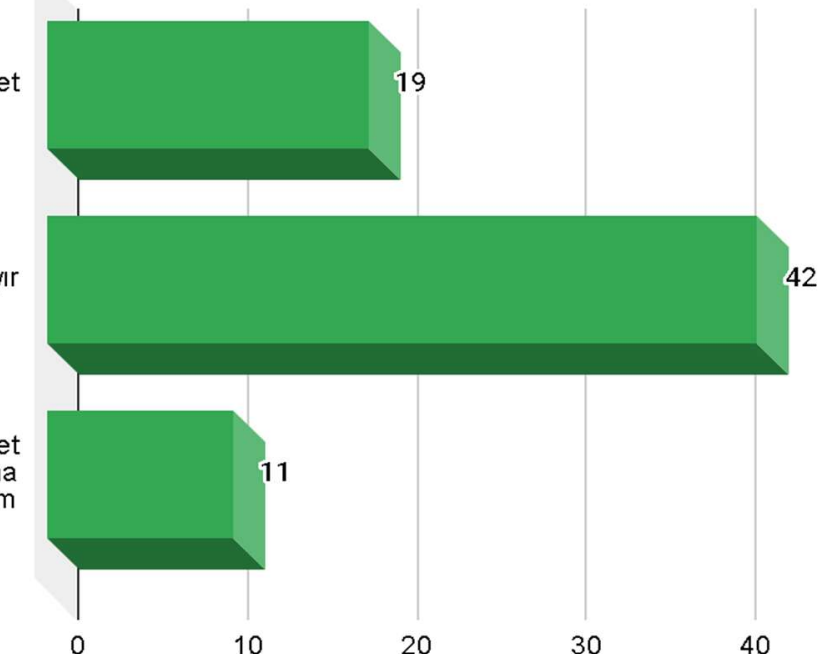
42

Grafik 9: Çalışma standartları

Kurum içi çevirmenlerin çoğunlukta olduğu bir dağılım içerisinde bu çevirmenlerin \%42'sinin herhangi bir sözleşme ile istihdam edilmiyor olmaları ise, sağllk kuruluşlarında değil, Toplum Merkezlerinde görev alan çevirmenler olarak sağlık kuruluşlarından hizmet alan kişilere eşlik ediyor olmaları şeklinde açıllanabilir.

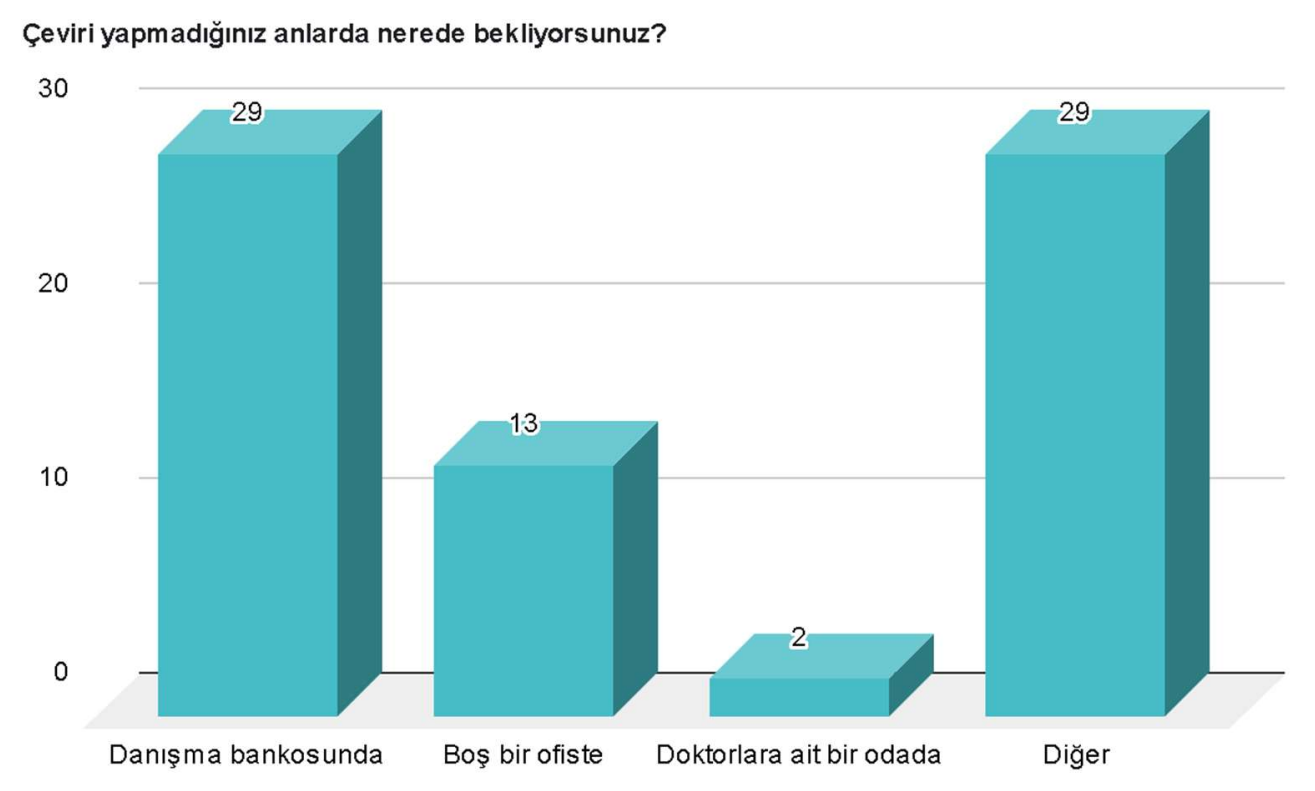

Grafik 10: İş yeri koşulları

Çeviri yapılmayan zamanlarda çevirmenin sağlık koşullarının, güvenliğinin ve hijyen şartlarının ne kadar temin edildiğini sorgulamak amacıyla yönlendirilen, çeviri yapılmadığı zamanlarda bekleme yeri 
Thinking about "New Normal" in healthcare interpreting and community interpreting in terms of COVID-19 conditions / F. Şan; R. Kahraman Duru (pp. 816-843)

olup olmadığına dair soruda, \%39,7'si danışmada, \%17,8’i boş bir ofiste, \%2,7'si doktorların bulunduğu odada ve yine \%39,7 oranındaki diğer seçeneği içinde \%13'lük bir kesimi de sağllk kurumu içinde (acil serviste, kurumun içinde, UHH Ofisi’nde) konumlandığını belirtmiştir. Buna ek olarak sunulan "diğger" seçeneğinde acil serviste bulunduğunu, uluslararası hasta hizmetleri için ayrılmış ofiste beklediğini, boş bir hastane odasında bulunduğunu ifade edenler de olmuştur. Ayrıca bir çevirmen hiç vakti olmadığını açıklayarak, öyle bir bekleme ortamının olmadığını ifade etmiştir. Bu sorunun yanıtları değerlendirilirken anketin uygulandığı kişilerin sağlık kurumlarında çalışan çevirmenlerle sınırlı olmadığı göz ardı edilmemelidir. Buna göre sağlık kurumunda çalışmıyorum (6 kişi), evden çalışıyorum (8 kişi), kuruma bağlı çalıştığım için sürekli hastanede bulunmuyorum (6 kişi) gibi yanıtların gelmesi de beklenen bir durumdur.

Çalışma koşullarının belirlenmesini amaçlayan sorulardan bir tanesi de sağlık kuruluşunda çeviri hizmeti verirken, çevirmenlerin uyması gereken kuralların olup olmadığıyla ilgilidir. İki kişinin yanıtsız bıraktığı soruya 13 çevirmen, kurum tarafından kendilerine açıklanmış herhangi bir kural olmadığını ifade etmiştir. 21 kişi ise sosyal mesafeyi korumalarının kural olarak belirlendiği yönünde yanıt vermiştir. Ayrıca; Sağlık Bakanlığının yayınlamış olduğu genelgede bulunan 14 kuralın geçerliliğine vurgu yapan bir kişi olmuştur. Yine bu çerçevede 2 kişi özellikle Covid-19 konusunda bilgilendirme yapıldığını ifade ederken, maske, eldiven kullanımı, dezenfektan kullanımı, el yıkama, vb. koruyucu ekipman ve uygulamaların kural olarak kendilerine anlatıldığını açıklamıştır. Toplum Merkezinde çalıştığını ifade eden 6 çevirmen, evde kalmaları ve evden telefonla çalışmaları konusunda kurallar belirlendiğini belirtmiştir. Buna ek olarak mevcut koşullar nedeniyle çalışma saatlerinin değiştiğinin ve 24 saat çalışma sistemine geçildiğinin ifade edilmesi, bazı çevirmenlerin iş yükünün fazlalığı konusunda ipucu vermiştir. Öte yandan yanıtlar arasında çeviri uygulamasında tıbbi terimlerin kullanılması ve bilginin birebir aktarılması konusunda hassasiyet gösterilmesi ile ilgili kuralların olduğu da açıklanmaktadır.

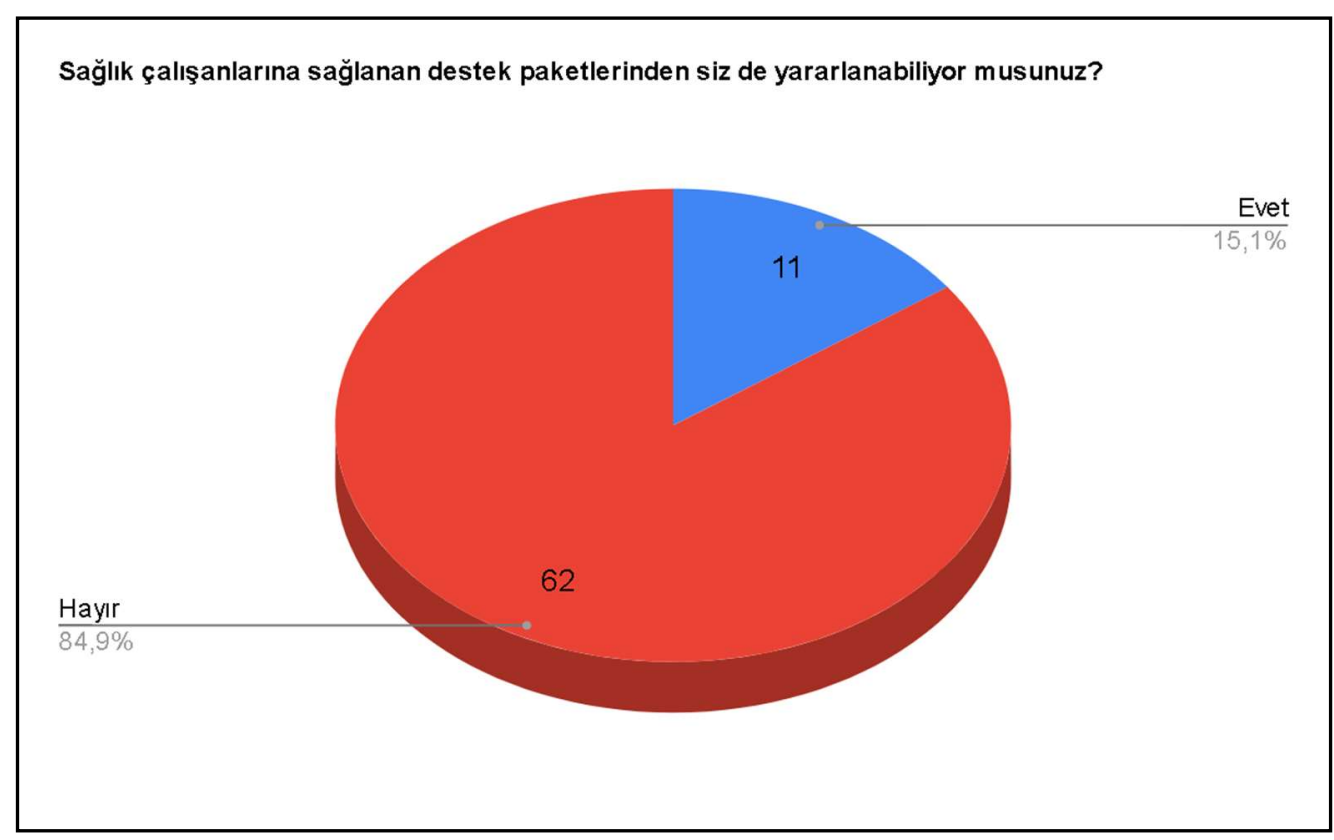

Grafik 11: Desteklerden yararlanma

Covid-19 süreci içerisinde özellikle çalışma şartları ve süreleri itibari ile bu süreçten hem maddi hem de manevi anlamda etkilenen hekim ve yardımcı sağlık personeli için pek çok kurum ve kuruluş destek 
paketleri sunmuştur. Araştırma kapsamında elde edilen veriler, ankete katılan kurum içi çevirmenlerin yoğunlukta olduğu yapı içerisinde, bu çevirmenlerin konumlarının, mevzuatta yer alan yardımcı sağlık personeli18 tanımına dahil olmadığı gibi, böylesine bir afet durumunda da verdiği hizmete rağmen destek paketi dışında tutularak, çevirmenin yine görünmezlik şemsiyesi altında bırakıldığı sonucuna götürmektedir.

\subsection{3. Çevirmen için zorlayıcı kişisel ve çevresel koşullar ve etkileri}

Diğer toplumsal hizmetlerin alındığı kurumlara kıyasla, sağlık kurumlarında çevirinin amacına ulaşması için, çevirmenin içinde bulunduğu iletişim durumunu duygusal olarak da yönetebilmesi ve eyleyicilik rolünü yerine getirmesi gerekir. Söz konusu ortamda, iletişimin dilsel ve kültürel farklılıkların ötesinde sağlıklı bir şekilde kurulamaması, insan hayatını tehdit edici bir duruma yol açabilir. Bunun yanı sıra, çevirmenler iletişim ortamındaki tarafların birbiriyle çelişen talep ve beklentilerini sağlama durumunda oldukça zor bir süreci aşmakla yükümlü hale gelmektedir (Kainz, Prunc ve Schögler, 2011). Bir taraftan çeviri yapılan kişi, diğer taraftan sağlı hizmetinin alındığı kurumun kuralları sürecin kolaylığı/zorlayıcılı̆̆ı üzerinde belirleyici olabilmektedir.

\section{a) Kişisel koşullar ve etkileri}

“...çevirmenlerin yalnızca dilsel seçimlerinde değil, genel çerçevede verilen sağlık çevirmenliği hizmetinin kalitesini de etkileyebilecek durumlarda çevirmenlerin aldıkları kararların öznelliği, özellikle kötü haber verme bağlamında çevirmene ciddi bir sorumluluk yüklemektedir.” (Duman 2018: 92)

Normal zamandaki çalışma koşullarında bile çevirmen için büyük bir sorumluluk olarak betimlenen kötü haber verme süreci ve bu aşamadaki dış faktörlerin belirleyiciliği, Covid- 19 gibi ölümcül vakaların yoğunlukta olduğu salgın hallerinde çevirmenin yükünü çok daha fazla zorlaştırmaktadır.

Ancak kurumsal yapı içinde roller ne kadar belirlenmiş olur ise, etik çerçeve ne kadar iyi çizilmiş ve çevirmen de yerine getirmekte olduğu göreve bir yardımcı sağlık personeli olarak ne kadar yüksek donanım ile hakim ise, bu süreçteki çeviri faaliyetine etkisi de aynı oranda azalacaktır. Aşağıdaki grafikte yer alan çevirmenlerin \%39 oranındaki ağırlıklı bir bölümü, kurum içi görev yapmalarından dolayı hasta ile hastane süreçlerine yatkınlıklarının fazla olmasının, süreçte iyi-kötü haberin aktarımında bir zorluk yaratmadığını belirtmiş; \%8 gibi bir oran bu konuda zorlandığını dile getirmiş, \%3’ü yoğun çalışma koşullarından sürecin içinde özdeğerlendirme yapamayacak kadar vakit sıkıntısı yaşadığını dile getirmiştir. Yanıtlar incelendiğinde "diğer" seçeneğini işaretleyen 10 kişi böyle bir durumla karşılaşmadığını açıklarken, 16 kişi de evden telefonla çalışması, daha çok yazılı çeviri yapması, STK'ya bağlı çalışması ya da hastalarla iletişim gerektirmeyen bir görevde olması gibi sebeplerle, hasta ile böyle bir bilgi paylaşmak zorunda kalmadı̆̆ını belirtmiştir. ${ }_{18}$ https://www.resmigazete.gov.tr/eskiler/2014/05/20140522-14.htm
https://www.resmigazete.gov.tr/eskiler/2014/12/20141218-6.htm 
Thinking about "New Normal" in healthcare interpreting and community interpreting in terms of COVID-19 conditions / F. Şan; R. Kahraman Duru (pp. 816-843)

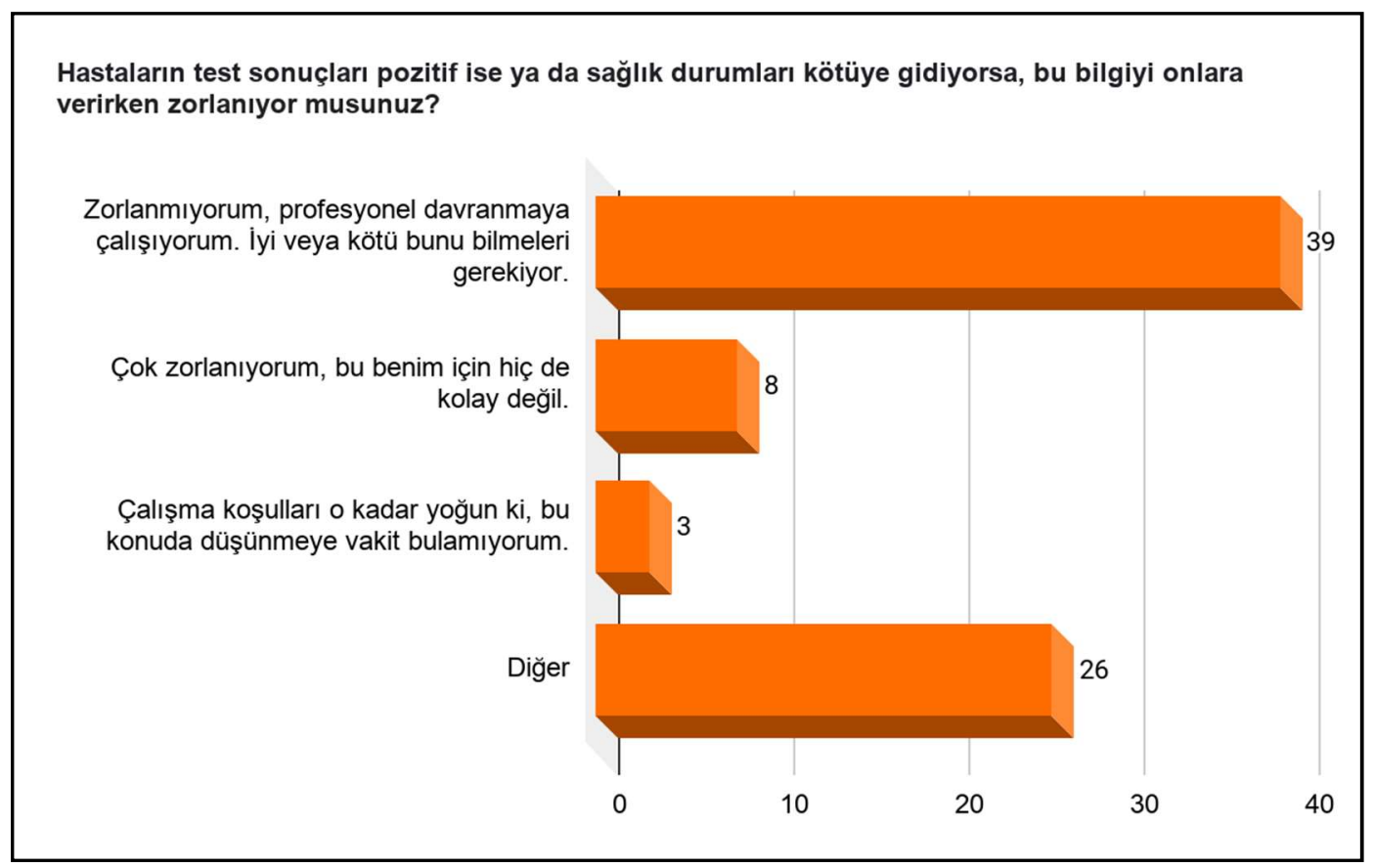

Grafik 12: Kişisel koşullar

Covid-19 Pandemi sürecini, normal zamanlardaki sağlık hizmetleri sürecinden en bariz şekilde ayıran özelliklerden bir tanesi de iletişim ve tedavi süreci üçgeninin her üç kesiminin de süreçten hayati risk açısından eş düzeyde etkilenebilir durumda olmalarıdır. Nitekim bu hastalığa yakalanarak yaşamlarını yitiren ya da hastalığı atlatan çok sayıda sağlık çalışanı ve yardımcı sağlık personeli olduğu bilinmektedir. Ancak bu rapora herhangi bir şekilde yansıyan çevirmen bilgisi elde bulunmamaktadır ${ }^{19}$

Olayın asıl post-travmatik, stres bozukluğu şeklinde afet sonrası toparlanma sürecinde ortaya çıkan boyutuna işaret edebilecek bir diğer bulgu da, olay esnasında çevirmenlerin içinde bulundukları durumu psikolojik olarak nasıl algıladıkları ve bundan ne oranda etkilendikleridir.

Çevirmenlere, söz konusu psikolojik etkilere dair ipucu verebilecek, bir soru yöneltilmiştir. Aşağıdaki grafikten çevirmenlerin \%30,1 (22 kişi) gibi bir çoğunluğunun orta derecede de olsa korktuklarını, bunu \%24,7 (18 kişi) ve \%17,8 (13 kişi) gibi korkuyorum ve çok korkuyorum oranlarının izlediğini, korkmuyorum (10 kişi) ve hayır hiç korkmuyorum (10 kişi) diyen çevirmenlerin de \%27,4 gibi bir oranla kendilerini ifade ettikleri görülmektedir.

19 https://www.ttb.org.tr/haber_goster.php?Guid=e34429ca-846e-11ea-9137-e385f12afb6d 
Hastalığın bulaşmasından korkuyor musunuz? Derecelendiriniz.

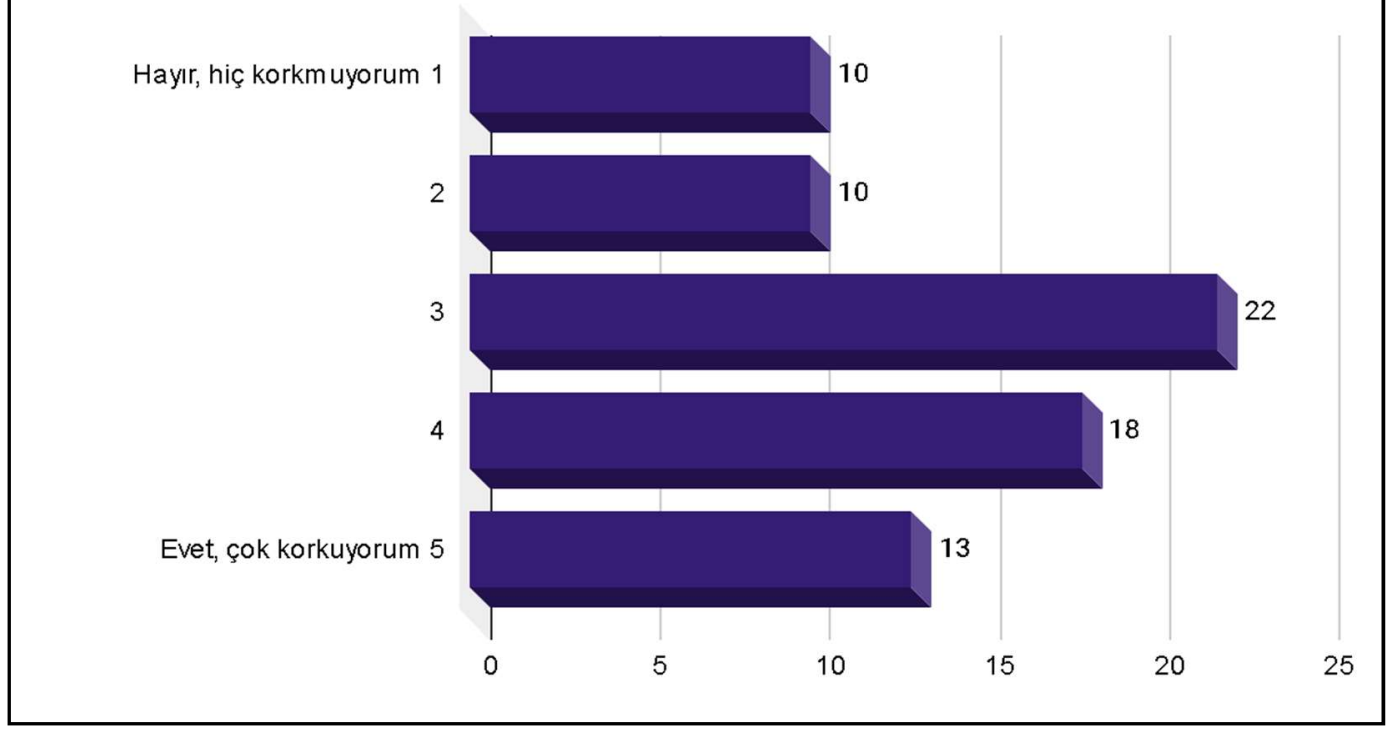

Grafik 13: Hastalığın bulaşma riskinin çevirmen üzerindeki etkisi

Pandemi koşullarında çalışmanın çevirmenler üzerinde yarattı̆̆ı etkiyi tespit etmeyi amaçlayan sorulardan biri de çevirmenlerin psikolojik durumu ile ilgilidir. Yaşadıkları ve gördüklerinin çevirmenleri psikolojik olarak nasıl etkilediği ile ilgili soruya verilen yanıtlar farklı bakış açıları sunmaktadır. Beş kişinin yanıtlamadığı soruyu, çevirmenlerin \%27,8'i (20 çevirmen), "normal karşılıyorum, işe profesyonel yaklaşıyorum, sağlık kuruluşlarının aldığı tedbirleri uyguladığım için çok etkilenmiyorum, psikolojik olarak hiç etkilenmiyorum” gibi açılamalarla etkilenmediği yönünde yanıtlamıştır. Yapılan ankete göre orta düzeyde etkilendiğini ifade edenlerin sayısı 9'dur. Koşulların psikolojik etkisinin az olduğunu ve etkilenmemeye çalıştıklarını belirten çevirmenlerin bazılarının, bu durumu görmezden gelmeye çalışarak işlerine odaklanma çabası içerisinde oldukları yaptıkları açıklamalar vasıtasıyla gözlemlenmiştir.

Buna karşın Covid-19 koşullarında çevirmenlik yapmanın olumsuz yönde etkilediğini ifade edenlerin sayısı oldukça fazladır. Bu bağlamda 38 çevirmenin (\%52,8 oranla anketi dolduranların yarısından fazlasına denk gelmektedir), çeşitli nedenlerle psikolojik olarak çok etkilendiği görülmüştür. Günümüz koşullarında sağlık çevirmenliğinin sınırlarını aşarak afet ve acil durumu da içine alan bir çeviri faaliyetinin söz konusu olduğunu vurgulamak gerekir. Bunu da dikkate alarak soruya verilen yanıtlar incelendiğinde, çevirmenlerin iki taraf arasında söyleneni aktaran bir kişi olmanın ötesinde, 'toplumun parçası birey' olarak da incelenmesi ve açılanması gerektiği ortaya çıkmaktadır. Çevirmen işini yapmakla beraber, olmuş ve bitmiş bir afet sonrasındaki sağlık müdahalesinden farklı olarak, pandemi ile karşı karşıya ve tehlike altında çalışmaktadır. Çevirmenlerin "endişe duyuyorum, endişelerim artıyor ve kendimden hatta en yakınımdan bile şüphe duyuyorum, hastalık kapacağım korkusu yaşıyorum, sevdiklerimi kaybetme korkusu yaşıyorum, kronik astım olduğumdan çok tedirginim, zaman zaman psikolojik olarak çıkmazda gibi hissediyorum, gelecekten umudum ve beklentim kalmıyor" gibi açıklamaları, söz konusu tehlikenin verdiği huzursuzluğun boyutunu ve psikolojik etkilerini görünür kılmaktadır. 
Thinking about "New Normal" in healthcare interpreting and community interpreting in terms of COVID-19 conditions / F. Şan; R. Kahraman Duru (pp. 816-843)

Dünyadaki hastaların ve ölümlü vaka sayılarının her geçen gün artması, bulaşma riskinden dolayı duyulan endişe, kaygı, tedirginlik, üzüntü, başkalarına bulaştırma korkusu, karamsarlık, odaklanamama, ölüm düşüncesi, gerginlik ve stres gibi cinsiyet ayrımı gözetmeksizin ortak deneyimlenen psikolojik durumlara dair ifadelerle şeklinde ortaya konulurken diğer yandan Grafik1 'deki dağılıma göre \%31'lik bir kesimden oluşan kadın grubunun kendi cinsiyetlerine özel eklenen bir diğer kaygısı da anne olma, küçük çocuğunu evde bırakma ve bundan dolayı duyulan ekstra kaygı şeklinde çeviri sürecine ve çalışma koşullarına olumsuz yansıdığı şeklinde ifade edilmektedir.

Açıklamalar incelendiğinde, sağlık çalışanlarıyla aynı ortamda görevini yapmakta olan çevirmenlerin, aynı düzeyde risk taşıyor olmaları sebebiyle, farklı şekillerde ifade etseler de büyük bir endişe taşıdıkları görünmektedir. Bu soruya çevirmenlerin verdiği yanıtlar incelendiğinde çevirmenin 3. kişi olarak işlerini yaptıkları "normalin” dışında bir durum yaşadıkları görülmektedir. Bunun anlamı, bilinen durumsallı̆̆ı dışına çıkılmasıdır; aynı zamanda risk altında olmaları nedeniyle, durumsallı̆̆a farklı bir boyut daha katılması söz konusudur. Dolayısıyla çevirmenlerin psikolojik olarak etkilendiği görmezden gelinmeyecek bir husus olarak algılanmalıdır.

Araştırmanın başında da ifade edildiği üzere afet olgusu afet öncesi hazırlık, afet ve afet sonrası iyileşme süreçleri olarak sınıflandırılabilirken, içinde bulunduğumuz pandemi bir afet türü gibi ele alınırsa, afetler gibi belirgin bir sürede gerçekleşip sona eren bir süreç değildir, çevirmenin bu süreçte içinde bizzat yaşamsal kaynakları tehdit altındadır, durumsallık dediğimiz durumlar her geçen gün değişmekte olduğundan atfedilmiş rollerinin bir kez daha "yeni normal" bağlamında, yardımcı sağlık personeli tanımı içinde de konumlandırılmasını gerekli kılmaktadır.

\section{b) Çevresel koşullar ve etkileri}

Sağlık alanında çalışan profesyoneller için gereken hijyen koşullarında bilgilendirme ve ekipman temini süreç içerisinde gerçekleştirilmiştir. Bu anlamda ulusal ve uluslararası anlamda kılavuzlar ve yönergeler yayınlanmıştır. Bunlardan hijyen koşullarının sağlanması ile ilgili en genel anlamda herkesi kapsayıcı hususlar şöyle sıralanabilmektedir:

- $\quad$ İş yeri sağlığı ve güvenliği risklerini en aza indirmek için gerekli tüm önleyici ve koruyucu önlemlerin alınmasını sağlamak için genel sorumluluk üstlenmek,

- Aşağıdakiler dahil olmak üzere iş yeri sağlığı ve güvenliği hakkında bilgi, talimat ve eğitim sağlamak;

- $\quad$ Enfeksiyonun önlenmesi ve kontrolü hakkında tazeleme eğitimi;

- Kişisel koruyucu ekipmanların (KKD) kullanılması, giyilmesi, çıkarılması ve atılması;

- Şüpheli veya teyit edilmiş COVID-19 hastalarına bakım yapan sağlı personeli ve diğer personele yeterli miktarda enfeksiyon önleme ve koruma tedbirleri ile KKE malzemesini (maske, eldiven, gözlük, önlük, el dezenfektanı, sabun ve su, temizlik malzemeleri), çalışanların bu tip iş yeri sağlığı ve güvenliği gereksinimleri için harcama yapmalarını gerektirmeyecek şekilde sağlamak ${ }^{20}$. 


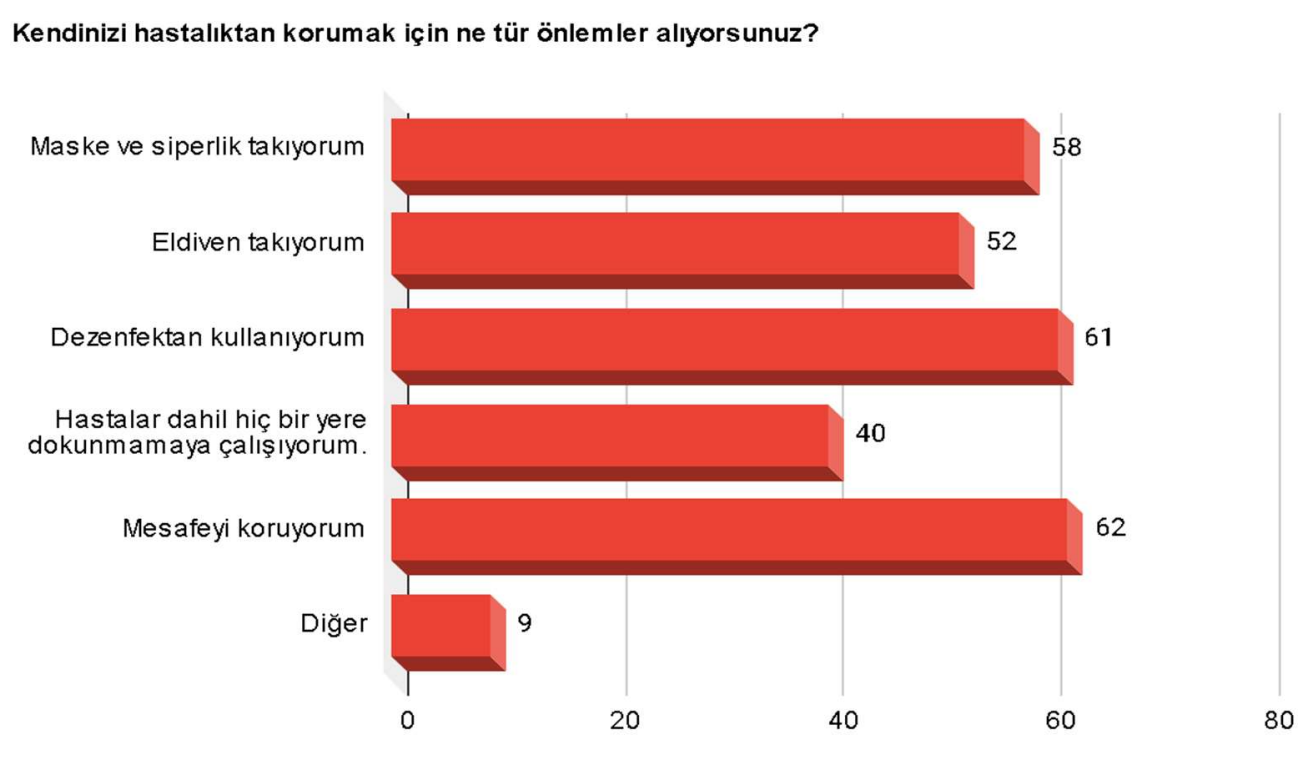

Grafik 14: Alınan tedbirler

Buradaki geri bildirim sonuçlarına bakıldığında, Dünya Sağlık Örgütü’nün yukarıda sıralanan maddeleri esas alındığında maske ve siperlik, eldiven, dezenfektan ve mesafe ve temasta bulunmama kurallarının uygulandığı görülmektedir. Diğer seçeneğini işaretleyenlerin bazıları işyeri tedbirlerinin haricinde özel hayatlarındaki uygulamalara da yer vermiştir. "Çeviri işlemlerini bitirdikten sonra kıyafetlerimi yıkıyorum, sıcak duş alıyorum, araç içini sürekli havalandırıyorum, sık sık kıyafet değiştiriyorum, el yıkıyorum, sağlıklı beslenmeye çalışıyorum” şekildeki açıklamaları buna örnektir.

Hijyen koşulları ve tedbirleri dışında çevirmenler çalışma koşullarının zorluklarına ilişkin aşağıda yer alan geri bildirimlerde bulunmuşlardır:

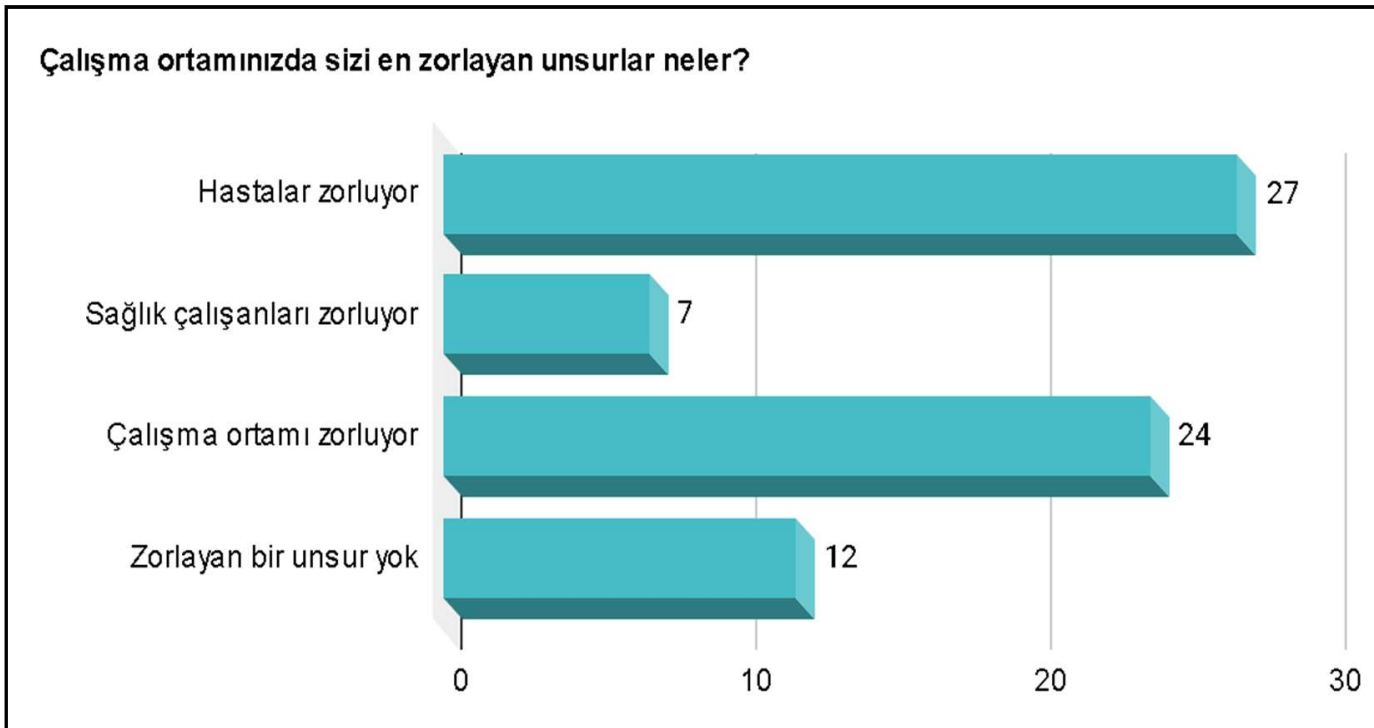

Grafik 15: Zorlayıcı unsurlar 
Thinking about "New Normal" in healthcare interpreting and community interpreting in terms of COVID-19 conditions / F. Şan; R. Kahraman Duru (pp. 816-843)

Çevirmenlere çalışma ortamlarında onları zorlayan unsurlar sorulmuştur. 4 kişinin yanıtsız bıraktığı soruda çevirmenlerin büyük çoğunluğu hastalar $(\% 38,6)$ ve çalışma ortamının $(\% 34,3)$ kendilerini zorladığını ifade etmektedir. Grafikten de görülebileceği gibi sağlık çalışanlarını kendilerini zorlayan unsur olarak görenlerin oranı \%10 iken, zorlayıcı bir unsurun olmadığı yönünde işaretleme yapanlar da vardır $(\% 17,1)$. Bu seçeneği işaretleyenler bunun nedenini evden çalışıyor ya da devamlı olarak hastanede bulunmuyor olmaları üzerinden açıllamaktadırlar.

Bunlara ek olarak çevirmenler müracaatçlların bilinçsizliği, sosyal mesafeye uymayan insanların olması, hastaların paniklemesi, hasta yakınlarının davranışları, kriz yönetimi eksikliği gibi hususlardan yakınmaktadır. Öte yandan toplum çevirmenliğinde sıkça rastlanan bir durumdan, güven konusundan da söz edildiği görülmektedir. Bazı hastaların çevirmene ve çevirinin doğruluğuna karşı güven duymadığı durumların olduğunu ifade eden bir çevirmen, aynı zamanda sağlık çalışanlarının bekletmesi ya da o an için yardımcı olmaması nedeniyle ayrımcılık ve milliyetçilikle suçlandıklarının altını çizmektedir. Karşlıklı güvenin temini iletişim akışının en önde gelen unsurudur. Bu hem sağlık personeli ile hasta, hem hasta ile çevirmen, hem de sağllk personeli ve çevirmen arasında inşa edilmesi gereken üçlü bir yapıdır. Burada karşılaşılan herhangi bir engel, sonrasında sağlık gibi hayati bir öneme sahip ihtiyacın karşılanmasında aksaklıklara yol açacağı gibi, tarafsızlık ve nesnellik ilkelerini askıya alan bir tutumu beraberinde getirebilecektir.

\subsection{4. Çevirmen görüşleri}

Anket çalışmasının amaçlarından biri de Covid-19 koşullarında çeviri hizmetlerini ve çevirmenlerin koşullarını, çevirmenlerin bakış açısıyla ortaya koymaktır. Tam da bu amaca hizmet etmesi için çevirmenlerin çalışma koşulları iyileştirilmesi ve genel düşünceleri ile ilgili görüşlerine başvurulmuştur. Bu sorulardan bir tanesi de, sağlık çalışanlarına yönelik koruyucu ve destekleyici çalışmaların, sağllk çalışanları ile benzer koşullarda çalışan ve risk grubunda olan çevirmenler için de yapılıp yapılmaması konusundaki görüşleriyle ilgilidir.

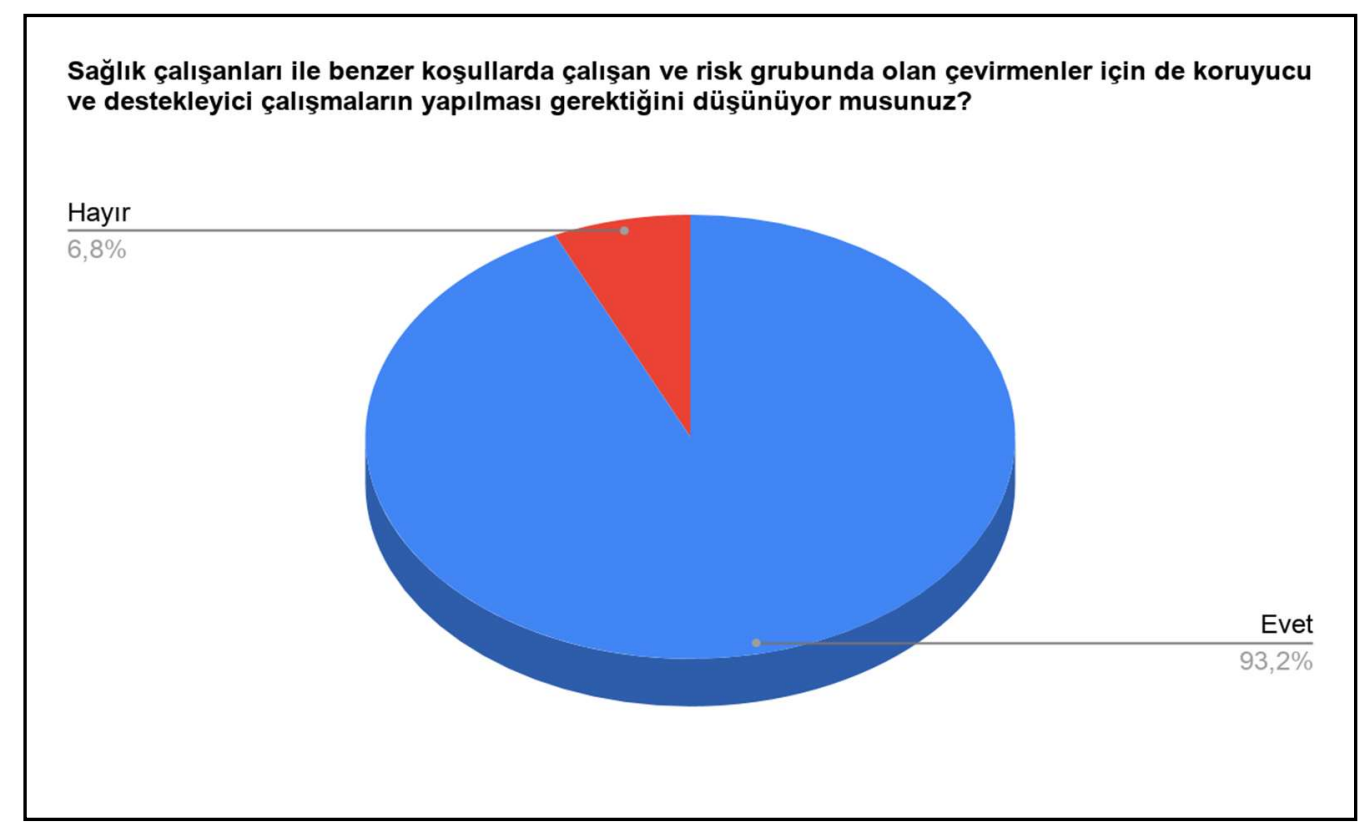

Grafik 16: Destekleyici ve koruyucu çalişmalar 
Grafikten de görüleceği gibi çevirmenlerin neredeyse tamamının verdiği yanıt, koruyucu ve destekleyici çalışmaların eksikliğine işaret etmektedir. Bu yanıtı 73 çevirmenin $68^{\prime}$ i vermiştir. Ne tür eksiklerin olduğu ve hangi konularda çalışmalar yapılması gerektiği ile ilgili olarak sorulan açı uçlu soruyu çevirmenlerin \%49,3’ü yanıtsız bırakmıştır. Buna karşılık yanıtlayanların önemli eksikliklere dikkat çektiğini söylemek yanlış olmayacaktır. Yanıtların detaylarından söz edilecek olursa, birçok çevirmen sağlık tedbirleri nedeniyle önlemler alınması gerektiğini düşünmektedir. Bu konuda çalışma gerektiğini, tedbirlerin alınması gerektiğini ifade eden çok fazla çevirmen olduğu görülmüştür (bazı yanıtlar: maske eldiven ve dezenfektan dağıtılması, ayrıca test yapılması lazım, gerekli koruyucu malzemelerin bolca bulunması, özellikle tulum ve siperlik desteği, malzeme ihtiyacının giderilmesi ve sosyal mesafe, çevirmenlerin de kıyafetleri sağlık çalışanı gibi olmalıdır, hijyenik ortamın sağlanması, tüm çalışanların aynı hassasiyeti göstermesinin sağlanması önemli, ihtiyaç duyulan koruyucular maske eldiven, rutin test uygulanmalı, kurumda çalışanlara aralıkla test yapılması iyi olur, koruyucu giysiler verilmesi, daha fazla tedbir ve önlem alınması, koruyucu kıyafetlerin temin edilmesi, semptomlar görülmeden kontrol testi yapılabilir). Bu çerçevede verilen diğer yanıtlarda da çevirmenlere hastane içerisinde ayrı bir ofis verilmesi, kurum içi çevirmenlerin haklarının tanımlanması, çalışma saatlerinin daha kısa ya da esnek olacak şekilde düzenlenmesi, yedekle ya da nöbetleşerek çalışılması gibi yorucu ve sıkıntılı çalışma şartlarını rahatlatıcı talepler ifade edilmiştir. Mevcut Covid-19 koşullarını dikkate alarak, kurumda çalışan sayısının en aza indirilmesi gerektiğine sıkça vurgu yapılmaktadır. Buna bağlı olarak uzaktan çalışmayı olanaklı kılacak telefon, telekonferans gibi teknolojik çalışma sistemlerinin geliştirilmesi talebi de dikkat çekmektedir.

Soruya verilen bazı yanıtların mevcut koşulların ötesinde sağlık çevirmenlerinin genel durumuna işaret ettiği de görülmüştür. Çevirmenler, sağlık alanında çalışmaları nedeniyle alan bilgisine ihtiyaç duyduklarının farkında olarak sağlık çalışanlarına verilen eğitimin kendilerine de verilmesi gerektiğinin altını çizerken, bu alanda çalışacak çevirmenlerin kendisini bilgi açısından geliştirmesi gerektiğine vurgu yapmaktadır. Özellikle sağlık alanında insan hayatının etkilenmesi söz konusu olduğundan, çevirmenlere de büyük sorumluluk düşmektedir. İşleyişi bilmek, terminolojiye hâkim olmak, pozisyonunu ve sınırlarını ayarlayabilmek önemli unsurlar arasında yer almaktadır. Bu elbette aynı zamanda profesyonellik olarak da adlandırllabilir. Bu yönde bir talep sadece çevirmenler tarafından değil, sağlıklı bir iletişim ortamının oluşmasına en çok ihtiyaç duyan sağlık çalışanları ve hastalar tarafından da gelmeli aslında. Doktorun işini doğru ve iyi yapması için işleyişin önemli bir parçası çevirmen, diğer deyişle dil engeli olanların da eşit hizmet almasında vazgeçilmez bir aktör. Çevirmen istihdamı en başta onların talebi olmalı.

Ankette, çevirmenlerin görüşüne başvurmayı amaçlayan bölümde, özellikle sorularda atlanmış bir husus varsa ya da daha farklı bir yaklaşım aktarmak istiyorlarsa, kısıtlama getirilmeden bunu ifade edebilmeleri için olanak sunulmuştur. Eklemek istediğiniz bir şey var mı? sorusunu büyük çoğunluk yanıtsız bırakırken, çevirmenlerin bazıları, sağlık ekibi ile aynı riskleri taşımaları nedeniyle maaşlarına zam gelmesi talebinde bulunmuştur. Kurumlarda çevirmenleri sağlık çalışanlarından ayrı tutmadan, onlara verilen eğitimleri almaları gerektiğine de vurgu yapıldığı görülmüşsür. Çalışma koşullarının ağırlığına işaret eden bir başka yanıt, çevirmenlerin de risk altında çalıştıkları için çok fazla etkilendiklerini, çarpıcı şekilde ortaya koymaktadır:

"Biz bu işi yaparken yüreğimizle yapıyoruz. Bizler zorunlu işe gidiyoruz. Bir anne olarak endişeliyim. Bana bir şey olursa çocuklarıma bakın, onlara sahip çıkı"

Bu ifade işsizlik artarken, kurumlar, firmalar ve devlet ekonomik darboğaza girerken, her şeye rağmen elindekini koruma çabası içindeki sağlık çalışanların çaresizliği olarak okunabilir. 
Bu soruya verilen yanıtlar pandemi özelinde değerlendirildiğinde, iş süreçlerinin daha da zorlaşmasıyla ücret yetersizliği ve çalışma koşulları konusundaki algılarının daha da güçlendiği ve dile getirildiği şeklinde yorumlanabilir.

\section{Sonuç yerine: Toplum çevirmenliğinde "Yeni normal”i düşünmek}

İş, spor, sağlık, üniversite, göç vb. çeşitli nedenlerle Türkiye'de bulunanlar, ülke dilini bilmiyor olmaları sebebiyle, birçok alanda iletişim sorunu yaşamaktadır. Burada toplum çevirmenlerine ihtiyaç duyanların büyük çoğunluğunu oluşturanların, 2011 yllı itibariyle Suriye'den gelen ve geçici koruma altına alınan kişiler olduğu söylenebilir. Bu bağlamda en fazla sağlık alanında toplum çevirmenlerine ihtiyaç duyulmakla beraber, bu ihtiyaca paralel olarak, toplum çevirmenliğini konu alan bilimsel çalışmalara, yine en fazla sağlık çevirmenliğinin konu olduğunu söylemek yanlış olmayacaktır (Şan ve Koçlu, 2020: 802). Bu da sağlık alanının hem sahada hem de araştırmalarda önemli bir yere sahip olduğunu ortaya koymaktadır.

Araştırmanın başında da ifade edildiği gibi Türkiye'de, toplum çevirmenliğinin bir alt uygulama alanı olarak sağlık çevirmenliği 15.12.2018 tarihli Mesleki Yeterlilik Kurumu Ulusal Yeterlilik Belgesi kapsamında "normal" çalışma koşulları bağlamında yasal bir zemin kazanma yolunda önemli bir ilerleme kaydetmiştir. Ancak bu standartlar bugüne kadar karşlaşılmış "normal" süreçleri tanımlamaktadır. Söz konusu standartların, bu araştırmaya konu olan pandemi gibi sağlık hizmetinin kapsamının genişlediği ve hazırlıklı bulunul(a)mayan durumlar için, sağlık çevirmeni, sağlık çalışanı ve çeviri hizmetinden faydalanacaklar açısından daha güvenli bir çalışma ortamını tanımlayacak özellikte olup olmadığının yeniden gözden geçirilmesinde fayda vardır. Önemli olan, standartların ve eyleyicilerin boyutu ve niteliği değişebilecek afete/krize dönüşebilecek durumlara uyum sağlayabilecek esneklikte olmalarıdır.

"Yeni normal" kavramı ile sağlık çevirmenliği sürecinde başvurulan araçlardan telefonun yanına, gelişen teknolojilerle birlikte video konferans sistemlerinin, internet ve diğer teknolojilerin de girmesi, sürecin işleyişinde ve çıktılarında da farklılıkları beraberinde getirmektedir. Mesleki yeterlilikler çerçevesine dönüp belki de bu yeni araçların gereklilikleri gözüyle bir daha bakmak gerekmektedir. Bu tür araçlar üzerinden çevirmenin gerektiğinde çeviri yapabilecek yetkinlikte olup olmadı̆̆ 1 ve uygun altyapının çeviri sürecinin sağlıklı akışına olanak verecek en güvenli şekilde yapılandırılıp yapılandırılmadığı çeviri süreci ile ilgili iki önemli nokta olarak öne çıkmıştır.

Anket sonuçlarına göre çevirmen profilinde kurum içi çevirmenlerin görece daha büyük oranda yer almaları, dolayısıyla kurumsal standartlara tabi olup Uluslararası Hasta Hizmetleri çalışanı ya da çevirmen olarak görev yapıyor olmaları, ancak kurumsal standartlar, destek paketleri ve imkanlardan bir hekim ve yardımcı sağlık personeli statüsünde faydalanamıyor oluşları, bu araştırma sonucunda ortaya çıkan önemli bir eksikliğe işaret etmektedir.

Yine yeterlilikler çerçevesinde çalışma koşulları bağlamında stres yönetimi ve çalışma süreçlerinde kalite ve verimlilik gibi kısımlarının; pandemi süreci esnasında çalışma ortamında bekleme alanı, bekleme süresi, çalışma ortamının hijyeni, Covid-19 gibi yaşamsal tehdit unsuru taşıyan bir durumla karşı karşıya kalındığı için belki yeterliliklerin de “yeni”den sorgulanmasını ve kapsamını genişletmeyi gerektirebilir. 
Çevirmenler ağırlıklı olarak bu süreçten yalnızca fiziksel değil aynı zamanda psikolojik anlamda da endişeli olduklarını, korku duyduklarını dile getirirken, içinde bulundukları stres koşulları ile baş etmede zorluk çektiklerini ifade etmektedirler. Bu durum hem çevirmen açısından hem de çeviri süreçlerinin sağlıklı akması açısından öncelikli olarak ele alınması gereken noktalardan biridir. Tıpkı hekimler ve yardımcı sağlık personelinin alması gereken psikolojik destek benzeri uygulamalar gibi, çevirmenlere de bu noktada destek verilmesi hayati önem taşımaktadır.

Çevirmene karşı ayrımcı tutumlar, güven inşasında yaşanan aksaklıklar yanında, istihdamın genelinde uygulanan daha az kişi ile daha az çalışma saati uygulaması, bekleme alanlarının, uygun koruyucu ekipman ve malzemelerin sağlanması, bunların yanı sıra hizmet içi eğitimlerin yapılandırılıp sıklaştırılması gibi hususlara çevirmenler pek çok sorunun yanıtında yer vermişlerdir.

Sağlık çevirmenliğinin, "normal” yaşamsal şartlarda, standart ve protokolleri belli olan, sağlık turizmi kapsamında uygulandığı koşullarla, insan kaynaklı/biyolojik bir afet sırasında ve sonrasında verilen sağlık hizmetlerindeki çeviri koşulları açısından karşılaştırmalı olarak ele alınıp ayrıştırılması gerekmektedir.

İçinde bulunulan pandemi süreci daha uzun soluklu bir "yeni” bir bağlamda ele alınması gereken bir afet türü olarak öncesinde hazırlık, afet sırası ve sonrası iyileşme süreçleri olarak sinıflandırılmalıdır. Toplum çevirmenliğinin Türkiye'deki ilk örneklerinden Afette Rehber Çevirmenlik organizasyonunun yapısının 13 yıllık dönemde değişen koşullarını değerlendiren ${ }^{21}$ Bulut ve Kurultay, yeni durumların ve buna bağlı olarak değişen koşulların Afet ve Acil Durum Çevirmenliği açısından irdelenmesi gerekliliğinin altını çizmektedir:

\begin{abstract}
“ARÇ’ın bir organizasyon olarak bundan sonraki süreçte nasıl ve ne ölçüde rol oynayacağı bugün yalnızca ARÇ’a indirgeyerek sorduğumuz bir sorudur. Oysa ADvA çevirmenliği sözlü çeviride hem her dönem üzerinde yeniden düşünülmesi gereken hem de farklı olanak ve yaklaşımların geliştirilebileceği bir uygulama ve araştırma alanı olarak varlık gösterecektir.” (Bulut ve Kurultay, 2012: 99)
\end{abstract}

Bulut ve Kurultay, afet çevirmeninin duruşunu belirleyen davranış kodlarının buyrukçu değil, birleştirici ve bütünleyici olduğu ölçüde esnek yapıda olmak ve farklı durumlarda farklı işlevlere karşılık gelmek zorunda olduğunu ifade etmektedir. Makalenin yazıldığı dönemde "yeni normal" kavramını kullanmamış olsalar da, aslında afet kavramının dinamik ve devingen yapısı ile bu kavramın içinden çıkan rollerin de buna uyum sağlayabilecek yapıda olmasının gerekliliğine işaret ettikleri söylenebilir. Her yeni afet türü yapısı gereği, kendi içinde, "normal" tanımlamalardan farklı, "yeni normal" tanımlamalara ihtiyaç duymaktadır.

Pandemi sürecinin de diğer afet türlerinde (örneğin deprem) olabildiği gibi bir anda sona ermeyeceği, hatta evrileceği gerçeği göz önünde tutulmalıdır. Sınırları ve standartları ile belirsizliğin ortasında kendini konumlandıran ve bu devamlılık arz eden süreç içinde bizzat yaşamsal kaynakları tehdit altında olan çevirmen, durumsallık ötesi bir noktada, belki de yardımcı sağlık personeli tanımı içinde bir kez daha "yeni normal" bağlamında yer bulmalıdır. Ancak çevirmenlerin bu konuda tek başlarına karar verici bir konumda olmaları elbette çok mümkün değildir.

Toplum Çevirmenliği genelinde değerlendirilecek olursa, sivil toplum yapısının gelişmesi, dayanışma bilincinin artması, araştırma kurumlarının bu sorunsallarla karşılaşılan alanlara ağırlık vermesi çok acil

21 Afet Çevirmenliğinin süreçsel dönüşümü konusunda bir çalışma da Doğan ve Kahraman tarafından yapılmıştır. Bkz. Doğan ve Kahraman (2011) 
Thinking about "New Normal" in healthcare interpreting and community interpreting in terms of COVID-19 conditions / F. Şan; R. Kahraman Duru (pp. 816-843)

bir gereklilik olarak ortaya çıkmıştır. Sorunların çözümleri, mesleki dayanışma içinde, standartlar ve kanunlar çerçevesinde rollerin yeniden düşünülmesi ile mümkün olacaktır.

Çevirinin ve çevirmenliğin sağlıklı bir şekilde "yeni” den yapılanması, bu meslek alanı ve meslek erbaplarını temsil eden sivil toplum örgütlerinin, kamu ve özel kurumların eşgüdüm içinde hareket ederek, ihtiyaç ve şartları belirlemelerine, "yeni normal"in tanımını ortaklaşa düşünmelerine bağlıdır.

\section{Kaynakça}

A National Code of Ethics for Interpreters in Healthcare. (2005). http://www.ncihc.org/ethics-andstandards-of-practice. Erişim Tarihi: 23.04.2020.

AFAD- 5902 sayılı Afet ve Acil Durum Yönetimi Başkanlığının Teşkilat ve Görevleri Hakkında Kanun: https://www.afad.gov.tr/kanunlar, Erişim Tarihi: 15.03.2020.

Aguilar-Solano, M. (2015). Non-professional volunteer interpreting as an institutionalized practice in healthcare: A study on interpreters' personal narratives. Translation \& Interpreting: The International Journal for Translation and Interpreting Research, 17(3), 132- 148.

AIIC- Appeal To Authorities. https://aiic.net/page/8947/appeal-to-authorities-by-aiic-fit-andwasli/lang/1, Erişim Tarihi: 08.03.2020

Angelelli, C. (2004). Medical interpreting and cross-cultural communication. UK: Cambridge University Press.

ATA-SPD, COVID-19 Pandemic: Impact and Effects on US T\&I Professionals, https://ataspd.org/2020/04/29/covid-19-pandemic-impact-and-effects-on-us-tiprofessionals/, Erişim Tarihi: 30.04.2020.

Bolden, G. (2000). Towards understanding practices of medical interpreting: Interpreters' involvement in history taking. Discourse Studies, 2(4), 387- 419.

Bührig, K. \& Meyer, B. (2009) Gespräche zwischen Patienten und Ärzten - ein- und mehrsprachige Anamnesen im Krankenhaus. In: N. Klusen \& A. Meusch (Hg.) Informiert und selbstbestimmt. Der mündige Bürger als mündiger Patient. Beiträge zum Gesundheitsmanagement 27. BadenBaden: Nomos Verlag, 189-205.

NIMDZİ- COVID-19 in Language Services: Early Considerations https://www.nimdzi.com/covid-19-inlanguage-services-early-considerations/, Erişim Tarihi: 28.04.2020.

Diriker, E. \& Tahir-Gürçağlar, Ş. (2004). Community Interpreting In Turkey. Çeviribilim ve Uygulamaları Dergisi, 14, 73-92.

Doğan, A. \& Kahraman, R. (2011). Emergency and Disaster Interpreting in Turkey- Ten Years of a Unique Endeavour. Hacettepe University Journal of Faculty of Letters, 28(2), 61-76.

Duman, D. (2018). Toplum Çevirmenliğine Yorumbilimsel Bir Yaklaşım: Sağlık Çevirmenliği ve Öznellik (Yayınlanmamış Doktora Tezi), Istanbul, Yıldız Teknik Üniversitesi.

Erdoğan, M., (2015), Türkiye'deki Suriyeliler: Toplumsal Kabul ve Uyum. İstanbul : Bilgi Üniversitesi.

EUATC (Avrupa Çeviri İşletmeleri Birliği) Translation Company Security Needs To Be Strengthened During COVID-19 Crisis, https://euatc.org/industry-hot-topics/translation-company-securitymeasures-need-to-be-strengthened-during-the-covid-19-crisis/, Erişim Tarihi: 27.04.2020.

Hale, S. B. (2007). Community interpreting. New York: Palgrave Macmillan.

İşyeri Hekimi ve Diğer Sağlık Personelinin Görev, Yetki, Sorumluluk ve Eğitimleri Hakkında Yönetmelikte Değişiklik Yapılmasina Pair https://www.resmigazete.gov.tr/eskiler/2014/12/20141218-6.htm, Erişim Tarihi: 20.04.2020.

Kahraman, R. (2003). Afette Rehber Çevirmenlik (Yayınlanmamış Doktora Tezi), İstanbul Üniversitesi.

Kahraman, R. (2010). Göç ve Çeviri: İltica Başvurularında Sözlü Çeviri Uygulamaları ve Toplum Çevirmeninin Rolü (Yayınlanmamış Doktora Tezi), İstanbul, İstanbul Üniversitesi. 
Kainz, C. \& Prunc E. \& Schögler R. (2011) Modelling the field of community interpreting: questions of methodology in research and training. Wien/ Berlin/Münster:Lit

Kurultay, T. \& Bulut, A. (2012). Toplum Çevirmenliğine Yeniden Bakışta Afette Rehber Çevirmenlik, İ.Ü. Çeviribilim Dergisi, Sayı:6 (2-2012), 75-102.

McNamee, R. (2004). The New Normal, The Penguin Group, New York.

Mesleki Yeterlilik Kurumu, Toplum Çevirmenliği Ulusal Yeterlilik Kriterleri: http://cdn.istanbul.edu.tr/FileHandler2.ashx?f=cevirmen-yeterlilikleri---toplum-cevirmeni--yayinlanan-taslak-15.12.2018.pdf, Erişim Tarihi: 23.04.2020.

Meyer, B. (2019) Wissen, Verstehen, Glauben? Eine Fallstudie zur patientenzentrierten Kommunikation und partizipativen Entscheidungsfindung. In: Spiritual Care, Band 8, Heft 4, Seiten 357-366.

Mikkelson, H. (2012). The professionalization of community interpreting. Çevrimiçi: https://aiic.net/page/1546/the-professionalization-of-community-interpreting/lang/1

Öztürk, T. (2015). Küresel Hareketlilik Etkisinde Türkiye'de Sağlık Çevirmenliği Uygulamaları: Çevirmen Görüşlerine Dayalı Bir Çalışma (Yayınlanmamış Doktora Tezi), Sakarya, Sakarya Üniversitesi.

Pöchhacker, F. (2004). Introducing Interpreting studies. London: Routledge.

Pöllabauer, S. (2010). Community Interpreting bei Ämtern der Sozialverwaltung: Auf der Suche nach Verständigung. Translationskultur revisited. N. Grbić and E. Prunč. Tübingen, Stauffenberg: 353-375.

Sağlık Meslek Mensupları ile Sağlık Hizmetlerinde Çalışan Diğer Meslek Mensuplarının İş Ve Görev Tanımlarına Dair Yönetmelik https://www.resmigazete.gov.tr/eskiler/2014/05/2014052214.htm, Erişim Tarihi: 20.04.2020.

Sağglk Bakanlı̆̆ı, Hastane Afet ve Acil Durum Planı (HAP) Hazırlama Kılavuzu: https://www.saglik.gov.tr/TR,1789/hastane-afet-ve-acil-durum-plani-hap-hazirlamakilavuzu.html, Erişim Tarihi: 27.04.2020

Sağlık Bakanlığı, Ulusal Pandemi Hazırlık Planı: https://hsgm.saglik.gov.tr/tr/bulasicihastaliklarhaberler/ulusal-pandemi-hazirlik-plani.html, Erişim Tarihi: 27.04.2020.

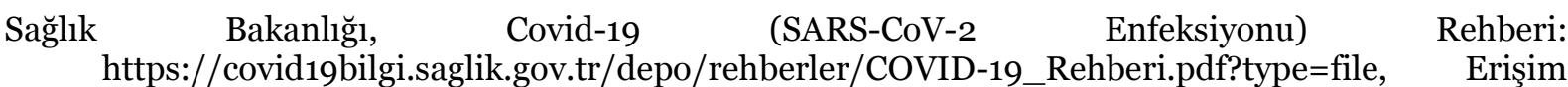
Tarihi: 27.04.2020

Slapp, M. A. (2004). Community Interpreting in Deutschland: Gegenwärtige Situation und Perspektiven für die Zukunft. Münih: Martin Meidenbauer Verlagsbuchhandlung.

Schouten, B. \& Ross, J. \& Zendedel, R. \& Meeuwesen, L. (2014). Informal Interpreters in Medical Settings. The Translator. 18. 311-338. 10.1080/13556509.2012.10799513.

Şan, F. \& Koçlu, S. (2020). Toplum Çevirmenliği Alanında Türkiye'de Yapılan Bilimsel Çalışmalar: Analiz ve Değerlendirme. RumeliDE Dil ve Edebiyat Araştırmaları Dergisi, (19), 785-808.

Şener, O. \& Kıncal, Ş. (2019). Role and Ethics in Healthcare Interpreting in Turkey. Çeviribilim ve Uygulamaları Dergisi , (27) , 201-219

Turan, D. (2016). Sağllk hizmetlerinde sözlü çeviri hizmetleri. Ankara: Grafiker Yayınları.

TTB- COVID-19 tanısı almış sağlık çalışanlarının sayısı artıyor. Hükümeti önlem almaya davet ediyoruz! https://www.ttb.org.tr/haber_goster.php?Guid=e34429ca-846e-11ea-9137-e385f12afb6d, Erişim Tarihi: 22.04.2020.

WHO: Coronavirus Disease (Covid-19) Outbreak: Rights, Roles And Responsibilities Of Health Workers, Including Key Considerations For Occupational Safety And Health. Çevrimiçi: https://www.who.int/docs/default-source/coronaviruse/who-rights-roles-respon-hw-covid19.pdf?sfvrsn=bcabd401_o, Erişim Tarihi: 23.04.2020 